\title{
Alterations in Skeletal Muscle Oxidative Phenotype in Mice Exposed to 3 Weeks of Normobaric Hypoxia
}

Citation for published version (APA):

Slot, I. G. M., Schols, A. M. W. J., De Theije, C. C., Snepvangers, F. J. M., \& Gosker, H. R. (2016).

Alterations in Skeletal Muscle Oxidative Phenotype in Mice Exposed to 3 Weeks of Normobaric Hypoxia. Journal of Cellular Physiology, 231(2), 377-392. https://doi.org/10.1002/jcp.25083

Document status and date:

Published: 01/02/2016

DOI:

10.1002/jcp.25083

Document Version:

Publisher's PDF, also known as Version of record

Document license:

Taverne

\section{Please check the document version of this publication:}

- A submitted manuscript is the version of the article upon submission and before peer-review. There can be important differences between the submitted version and the official published version of record.

People interested in the research are advised to contact the author for the final version of the publication, or visit the DOI to the publisher's website.

- The final author version and the galley proof are versions of the publication after peer review.

- The final published version features the final layout of the paper including the volume, issue and page numbers.

Link to publication

\footnotetext{
General rights rights.

- You may freely distribute the URL identifying the publication in the public portal. please follow below link for the End User Agreement:

www.umlib.nl/taverne-license

Take down policy

If you believe that this document breaches copyright please contact us at:

repository@maastrichtuniversity.nl

providing details and we will investigate your claim.
}

Copyright and moral rights for the publications made accessible in the public portal are retained by the authors and/or other copyright owners and it is a condition of accessing publications that users recognise and abide by the legal requirements associated with these

- Users may download and print one copy of any publication from the public portal for the purpose of private study or research.

- You may not further distribute the material or use it for any profit-making activity or commercial gain

If the publication is distributed under the terms of Article $25 \mathrm{fa}$ of the Dutch Copyright Act, indicated by the "Taverne" license above, 


\title{
Alterations in Skeletal Muscle Oxidative Phenotype in Mice Exposed to 3 Weeks of Normobaric Hypoxia
}

\author{
ILSE G.M. SLOT, ANNEMIE M.W.J. SCHOLS, CHIEL C. DE THEIJE, FRANK J.M. SNEPVANGERS, \\ AND HARRY R. GOSKER*
}

\author{
Department of Respiratory Medicine, NUTRIM School of Nutrition and Translational Research in Metabolism, Maastricht \\ University Medical Centre+, Maastricht, The Netherlands
}

\begin{abstract}
Skeletal muscle of patients with chronic respiratory failure is prone to loss of muscle mass and oxidative phenotype. Tissue hypoxia has been associated with cachexia and emphysema in humans. Experimental research on the role of hypoxia in loss of muscle oxidative phenotype, however, has yielded inconsistent results. Animal studies are frequently performed in young animals, which may hinder translation to generally older aged patients. Therefore, in this study, we tested the hypothesis that hypoxia induces loss of skeletal muscle oxidative phenotype in a model of aged ( 52 weeks) mice exposed to 3 weeks of hypoxia. Additional groups of young ( 4 weeks) and adult (I 2 weeks) mice were included to examine age effects. To verify hypoxia-induced cachexia, fat pad and muscle weights as well as muscle fiber cross-sectional areas were determined. Muscle oxidative phenotype was assessed by expression and activity of markers of mitochondrial metabolism and fiber-type distribution. A profound loss of muscle and fat was indeed accompanied by a slightly lower expression of markers of muscle oxidative capacity in the aged hypoxic mice. In contrast, hypoxia-associated changes of fiber-type composition were more prominent in the young mice. The differential response of the muscle of young, adult, and aged mice to hypoxia suggests that age matters and that the aged mouse is a better model for translation of findings to elderly patients with chronic respiratory disease. Furthermore, the findings warrant further mechanistic research into putative accelerating effects of hypoxia-induced loss of oxidative phenotype on the cachexia process in chronic respiratory disease.

J. Cell. Physiol. 23I: 377-392, 2016. (C) 2015 Wiley Periodicals, Inc.
\end{abstract}

Skeletal muscle of patients with chronic obstructive pulmonary disease (COPD) is often characterized by low muscle mass (Remels et al., 20I3), a reduced proportion of type I oxidative fibers and diminished oxidative capacity (Gosker et al., 2000; Decramer et al., 2005). In advanced disease stages hypoxia, a condition of inadequate oxygen content in a tissue, has been proposed as a driver of both phenotypic characteristics (Gosker et al., 2000; de Theije et al., 20I I; Turan et al., 20I I). Indeed the prevalence of weight loss and muscle atrophy is high in various respiratory disorders that are hallmarked by hypoxia, including acute exacerbations of COPD (Crul et al., 2010 ; Lainscak et al., 20I I), idiopathic pulmonary arterial hypertension (Batt et al., 20l4), and acute respiratory distress syndrome (ARDS) (Herridge et al., 2003), and hypoxia has been associated with reduced muscle mass (Schols et al., 1989). For the loss of muscle oxidative phenotype (Oxphen), a role for hypoxia is supported by observations of reduced proportions of oxidative type I fibers, decreased aerobic metabolism, and impaired oxidative capacity in skeletal muscle of patients with respiratory failure (RF) Jakobsson et al., 1990; Wuyam et al., 1992; Jakobsson et al., 1995). Furthermore, Filley et al. (1968) suggested already in 1968 that tissue hypoxia is responsible for cachexia in patients with end stage emphysema. Emphysema has also been associated with a more pronounced type I to II (oxidative to glycolytic) fiber-type shift in skeletal muscle (Gosker et al., 2002b). Moreover, hypoxemia often develops or worsens with acute exacerbations (Lainscak et al., 20l3), and patients suffering an acute exacerbation have been shown to have decreased expression of subunits of mitochondrial cytochrome $c$ oxidase and ATP synthase in the vastus lateralis muscle (Crul et al., 2010). The first report of an association between hypoxia and type I fiber proportion in human studies was probably by Jakobsson et al. (1990) who showed an association between low type I proportion and low arterial oxygen pressure in patients with RF. Moreover, Wuyam et al.
(1992) reported impaired oxidative capacity in patients with RF. A few years later, Jakobsson et al. (1995) also described decreased oxidative enzyme activities in quadriceps muscle of advanced COPD patients which were partly restored by longterm oxygen therapy (Jakobsson and Jorfeldt, 1995).

Previous studies involving healthy volunteers as well as experimental animal models gave inconsistent results with regard to hypoxia-associated loss of muscle oxidative phenotype. Human studies involved participants of mountaineering expeditions that were sampled before and after the expedition (Boutellier et al., 1983; Howald et al., 1990) and showed decreased activity of mitochondrial enzymes after hypoxia exposure. However, mountaineering expeditions are heavily confounded by strenuous physical activity (Hoppeler et al., 1990; Howald et al., 1990; Hoppeler and Desplanches, 1992). To control for confounders related to these expeditions,

Conflict of interest: The authors declare that there are no conflicts of interest.

Contract grant sponsor: Lung Foundation Netherlands; Contract grant number: NAF 3.2.05.038.

*Correspondence to: Harry Gosker, Department of Respiratory Medicine, NUTRIM School of Nutrition and Translational Research in Metabolism, Maastricht University Medical Centre+, PO Box 5800, 6202 AZ, Maastricht, The Netherlands.

E-mail: h.gosker@maastrichtuniversity.nl

Manuscript Received: 27 October 2014 Manuscript Accepted: 26 June 2015

Accepted manuscript online in Wiley Online Library (wileyonlinelibrary.com): 30 June 2015.

DOI: $10.1002 /$ jcp. 25083 
such as low temperature, dietary imbalance and extreme exercise, Green et al. (1989) studied participants who were placed in a hypobaric chamber. Enzyme activities of citrate synthase, succinate dehydrogenase, and hexokinase were repressed, but glycolytic enzymes other than hexokinase did not change and no fiber-type shift was observed (Green et al., 1989). Many animal studies were performed in rats (Itoh et al., 1990; Hirofuji et al., 1992; Takahashi et al., 1992; Takahashi et al., 1993; Abdelmalki et al., 1996; Sillau and Banchero, 1977; Bigard et al., 2000; Faucher et al., 2005; De Palma et al., 2007). Some of these studies report a fiber-type shift towards fast fibers (Itoh et al., 1990; Hirofuji et al., 1992; Itoh et al., 1992; Ishihara et al., 1994; Takahashi et al., 1996; Sillau and Banchero, 1977; Bigard et al., 2000; Faucher et al., 2005), whereas in others no change of fibertype composition is observed (Takahashi et al., 1992; Abdelmalki et al., 1996). In general, hypoxia appears to reduce oxidative enzyme activities (Takahashi et al., 1993; Abdelmalki et al., 1996; De Palma et al., 2007), although Takahashi et al. (1996) did not observe reduced oxidative enzyme activity by hypoxia. However, some of the reported changes in fiber-type composition and oxidative enzyme activities by hypoxia have been suggested to be confounded by hypoxia-associated anorexia (Abdelmalki et al., 1996).

Many of the animal studies have been conducted under hypobaric hypoxia (Itoh et al., 1990; Itoh et al., 1992; Ishihara et al., 1994; Bigard et al., 2000), whereas normobaric hypoxia would be most appropriate from a physiological and pathological perspective. Also, most of these studies have been conducted in rats, whereas mouse models are nowadays more suitable because of the availability of research tools that can be applied (e.g., antibodies, transgenes). Animal models for COPD are indeed primarily mouse models, but surprisingly until recently this did not yet include a well-established hypoxia model (Marcelino et al., 20I4). Moreover, as COPD mainly affects the elderly, using older animals would be most appropriate or at least preclude age-related variation in the investigated topic. To our knowledge, however, old animals are rarely studied to model disease factors of COPD, except for a recent report by van den Borst et al. (2013a) investigating effects of hypoxia on adipose tissue inflammation and metabolism. Indeed, the abovementioned animal studies were conducted in animals of different ages (juvenile and still developing to barely full-grown), with age-dependent outcomes (Ishihara et al., 1995). We recently investigated the direct effect of hypoxia on muscle oxidative phenotype in vitro (Slot et al., 20l4). In line with our hypothesis, markers of oxidative capacity were significantly reduced by hypoxia, but unexpectedly hypoxia stimulated expression of the oxidative type I myosin heavy chain (MyHC). In vitro cultured myotubes probably reflect the developmental stage of muscle in juvenile animals, further illustrating that age should be considered in animal models of COPD.

We, therefore, decided to conduct a methodological study on the effect of normobaric hypoxia on muscle oxidative phenotype in aged mice (52 weeks of age). We hypothesized that hypoxia induces loss of oxidative phenotype. In addition, we verified hypoxia-associated loss of muscle and fat mass and we determined protein oxidation levels. For comparison, also very young (4 weeks old, still growing) and adult ( 12 weeks old, limited muscle growth) mice were included.

\section{Materials and Methods \\ Experimental procedure}

A total of 76 male C57BL/6) mice (Charles River Laboratories, Wilmington, MA) at the age of 4 weeks (young), 12 weeks (adult), and 52 weeks (aged) were randomly divided over groups that were subsequently exposed to hypoxia ( $8 \%$ oxygen, $n=10$ for 4 weeks and 52 weeks, $\mathrm{n}=8$ for 12 weeks) or ambient air (normoxia, $\mathrm{n}=8$ per age group) for 21 days. Because decreased food intake is associated with hypoxia exposure and may act as a confounding factor in interpreting hypoxia-associated changes, an additional group of mice exposed to normoxia ( $n=8$ per age group) was pairfed to match the food intake of the hypoxic mice. Seven mice were excluded because of infection ( $I$ in 4 weeks hypoxic group, 2 in each of 4 weeks normoxic, and 52 weeks normoxic and hypoxic groups). Baseline characteristics but not the primary outcome (Oxphen) of only the 52-week-old normoxic and hypoxic but not pair-fed mice have been previously reported (van den Borst et al., 20I3a).

Mice were housed in experimental chambers at $21^{\circ} \mathrm{C}$ with a I2-h dark/light cycle and received standard chow (VI534-000 ssniff R/M$\mathrm{H}$, ssniff Spezialdiäten, Soest, Germany) and water ad libitum. For the hypoxia experiments, oxygen was replaced by nitrogen by the ProOx PIIO oxygen controller (BioSpherix, Lacona, NY) in a stepwise manner to create normobaric oxygen levels of I $2 \%$ (day I), $10 \%$ (day 2$)$, and finally $8 \%(60.8 \mathrm{mmHg})$ on day 3 and the remainder of the experiment. Three to four mice were housed per cage. Daily food intake was determined per cage. On day 21 , mice were anesthetized with isoflurane gas, the abdominal cavity was opened, and aortic blood was collected into a heparin-coated I-ml syringe (Becton Dickinson, Breda, The Netherlands). Oxygen levels and $\mathrm{pH}$ were measured immediately using the ABL 510 Blood Gas Analyzer (Radiometer; Diamond Diagnostics, Holliston, MA) and blood cell count was determined with the Coulter Ac T Diff Hematology Analyzer (Beckman Coulter, Woerden, The Netherlands).

Plasma was stored at $-80^{\circ} \mathrm{C}$ until further analyses. Lower limb skeletal muscles (gastrocnemius, tibialis anterior, soleus [SOL], extensor digitorum longus [EDL], and plantaris), were dissected and weighed. One of each muscle was embedded in Tissue-Tek (Sakura Finetek Europe, Zoeterwoude, The Netherlands) and frozen in melting isopentane precooled in liquid nitrogen and stored at $-80^{\circ} \mathrm{C}$ for histology. The other muscle was snap-frozen in liquid nitrogen and stored at $-80^{\circ} \mathrm{C}$ for molecular analyses. The protocol was approved by the Committee for Animal Care and Use of Maastricht University (project 2009-I5I).

\section{Immunohistochemistry}

Muscle cryosections $(7 \mu \mathrm{m})$ with fibers in transverse orientation were incubated with primary anti-myosin heavy chain $(\mathrm{MyHC}) \mathrm{I}$, antiMyHC Ila (both Developmental Studies Hybridoma Bank (DSHB), University of lowa, USA), and anti-laminin (Sigma, Zwijndrecht, The Netherlands) followed by secondary antibodies labeled with Alexa Fluor 555, Alexa Fluor 488, and Alexa Fluor 350 (Invitrogen, Breda, The Netherlands). Stained sections were microscopically photographed at 200× magnification (Nikon Eclipse E800; Nikon Instruments Europe, Amsterdam, The Netherlands). In a blinded fashion, fiber types were classified based on their MyHC isotype content (fiber type I and Ila positive for $\mathrm{MyHC}$ isotype I and lla, respectively; hybrid type I/lla positive for both MyHC isotypes I and Ila; types Ilb and Ilx together remain unstained) and fiber crosssectional area was measured with Lucia 4.82 software (Laboratory Imaging, Czech Republic) based on laminin staining of the basement membrane (Verdijk et al., 2007). The number of fibers analyzed per fiber type is listed in Supplemental Table SI.

\section{Enzyme activity assays and immunoblotting}

One soleus and one EDL muscle were each homogenized in $240 \mu \mathrm{l}$ ice-cold SET buffer ( $250 \mathrm{mM}$ sucrose, $2 \mathrm{mM}$ EDTA, $10 \mathrm{mM}$ Tris, $\mathrm{pH}$ 7.4) using a Mini-BeadBeater (BioSpec Products, Inc., Bartlesville, $\mathrm{OK}$ ) and incubated on ice for $10 \mathrm{~min}$. Samples were spun for $5 \mathrm{~min}$ at maximum speed $(20,8 \mathrm{I} \mathrm{g})$ in a cooled centrifuge and supernatant was collected. Pellets were snap-frozen in liquid nitrogen and stored at $-80^{\circ} \mathrm{C}$ for later analysis. Supernatants were divided into three aliquots. To the first aliquot, aqueous BSA solution was added to a final concentration of $I \%(v / v)$ and snap-frozen to be stored at $-80^{\circ} \mathrm{C}$ until analysis of enzymatic activity. The second aliquot was supplemented with $4 \times$ sample buffer $(250 \mathrm{mM}$ Tris $-\mathrm{HCl} \mathrm{pH} 6.8,8 \%$ 
(w/v) sodium dodecyl sulfate, $40 \%(\mathrm{v} / \mathrm{v})$ glycerol, $0.4 \mathrm{M}$

dithiothreitol, $0.02 \%(\mathrm{w} / \mathrm{v})$ bromophenol blue), and samples were snap-frozen and stored until analysis by Western blot. The third aliquot of lysate was used to determine the protein concentration with the bicinchoninic acid assay (Pierce, Thermo Fisher Scientific, Breda, The Netherlands) according to manufacturer's instructions.

Citrate synthase (CS, EC 2.3.3.I), 3-hydroxyacyl-CoA dehydrogenase (HADH, EC I.I.I.35), cytochrome $c$ oxidase (COX, EC I.9.3.I), and phosphofructokinase (PFK, EC 2.7.I.II) activities were assayed spectrophotometrically (Multiskan Spectrum; Thermo Labsystems, Breda, The Netherlands) as previously described (Ling et al., 1966; Shepherd and Garland, 1969; Bergmeyer et al., 1974; Gohil et al., 198I). Absolute CS, $\mathrm{HADH}, \mathrm{COX}$, and PFK activities were normalized to total protein.

For immunoblotting, $10 \mu \mathrm{g}$ of unboiled protein in sample buffer was separated by electrophoresis in a gradient gel (4-12\% Bis-Tris XT gel, Criterion, Bio-Rad, Veenendaal, The Netherlands) with XT MOPS running buffer (Bio-Rad). Samples from the same age group and the same muscle were run together on the same gel. Proteins were transferred to a $0.45 \mu \mathrm{m}$ nitrocellulose membrane (Protran, Schleicher and Schuell, 's-Hertogenbosch, The Netherlands) in transfer buffer ( $25 \mathrm{mM}$ Tris, $192 \mathrm{mM}$ glycine, $20 \%$ (v/v) methanol). After transfer, proteins were visualized using Ponceau $S$ staining solution (Sigma-Aldrich, St. Louis, MO). Membranes were subsequently blocked from nonspecific protein binding with blocking solution, which contains $5 \%(w / v)$ non-fat dry milk (Campina, Eindhoven, The Netherlands) in Tris-buffered saline with Tween-20 (TBST; $25 \mathrm{mM}$ Tris, $137 \mathrm{mM} \mathrm{NaCl}, 2.7 \mathrm{mM} \mathrm{KCl}$, $0.05 \%(\mathrm{v} / \mathrm{v})$ Tween-20, $\mathrm{pH} 7.4)$, for I $\mathrm{h}$ at room temperature, followed by incubation in primary antibody solution overnight at $4^{\circ} \mathrm{C}$ (mouse anti-Total OXPHOS Rodent WB Antibody Cocktail (MS604-300, Abcam, Cambridge, UK; the cocktail contains 5 mAbs, one each against $\mathrm{Cl}$ subunit NDUFB8, Cll-30kDa, CIII-Core protein 2, CIV subunit I and CV alpha subunit) or rabbit anti-PGC-I $\alpha$ antibody (\#516557, Calbiochem, Nottingham, United Kingdom) diluted I: I,000 in blocking solution). The next day, membranes were incubated in secondary antibody solution (peroxidase-labeled horse anti-mouse IgG or goat anti-rabbit IgG (PI-2000 and PI- I000, respectively; Vector Laboratories, Burlingame, CA) diluted I:5,000 in blocking solution) for $\mathrm{I} h$ at room temperature before incubation with enhanced chemiluminescence substrate (Pierce SuperSignal West PICO Chemiluminescent Substrate; Thermo Fisher Scientific). Protein bands were detected using LAS-3000 Luminescent Image Analyzer (Fujifilm, Tokyo, Japan). Bands were quantified using AIDA Image Analyzer software (Fujifilm) and corrected for loading differences by the Ponceau $S$ staining intensity.

Protein oxidation was detected with the Oxyblot kit according to the manufacturer's instructions (Chemicon International, Temecula, CA). Briefly, carbonyl groups in the protein side chains were derivatized to 2,4-dinitrophenylhydrazone (DNP) and immunoblotted according to the procedure described above. In addition, for each animal an underivatized sample was included, for which the derivatized sample was corrected in the analysis. After analysis of oxidation, the blot was reprobed for GAPDH (rabbit anti-GAPDH, \#2I 18; Cell Signaling Technology, Leiden, The Netherlands; procedure as described above) to correct for differences in protein loading.

\section{Gene expression analysis}

RNA was extracted from muscle tissue leftovers from cryosectioning using the RNeasy Fibrous Tissue kit (Qiagen, Venlo, The Netherlands) according to the supplier's protocol. Samples were homogenized using a Mini-BeadBeater (BioSpec Products, Inc.). After elution, RNA concentration was determined using a spectrophotometer (NanoDrop ND-1000, Isogen Lifescience, IJsselstein, The Netherlands) and integrity verified for a selection of samples by gel electrophoresis and on a Bioanalyzer (Agilent Technologies, Amstelveen, The Netherlands). Approximately
$500 \mathrm{ng}$ of RNA was reverse transcribed to cDNA with random hexamer primers according to the supplier's protocol (Transcriptor First Strand cDNA Synthesis kit, Roche Diagnostics, Woerden, The Netherlands). RT-qPCR primers were designed based on Ensembl transcript sequences and ordered from Sigma Genosys (Zwijndrecht, The Netherlands). Primer sequences are listed in Table I. RT-qPCR reactions contained SensiMix SYBR HiROX Kit (Quantace-Bioline, London, UK) with $300 \mathrm{nM}$ primers and were run in 384-well MicroAmp Optical 384-Well Reaction Plate (Applied Biosystems, Nieuwerkerk a/d IJssel, The Netherlands) on a 7900HT Fast Real-Time PCR System (Applied Biosystems). Standard curves, prepared from pooled cDNA, and melt curves were analyzed to verify efficiency and specificity of amplification. Seven reference genes (I8s, Axin I, B2m, Canx, Ppia, $R p l p 0$, and Tuba la) were measured and stability of expression was assessed by visual inspection of expression differences between the study groups and a stability assessment by geNorm

(Vandesompele et al., 2002). Eventually, six reference genes (all but $R p l p 0$ ) were used to calculate a geNorm factor, which was used to normalize expression levels of the target genes.

\section{Statistics}

Comparisons between the groups were made using Kruskal-Wallis non-parametric ANOVA (post hoc Mann-Whitney $U$ with Bonferroni correction), which is most appropriate for the current group sizes. Extreme outliers were removed from the analysis. To test the effect of age in the hypoxic group, per age group the values of the hypoxic animals were expressed as a percentage of those of the normoxic animals and compared as said above. Correlations were tested using the Pearson correlation coefficient. Analyses were performed using IBM SPSS Statistics 22.0 (IBM Corp., Armonk, NY). A $P$-value $<0.05$ was considered statistically significant.

Results

\section{Arterial blood gas and hematological adaptations}

The arterial blood of hypoxic mice of all ages showed increased acidosis, hypoxemia, and polycythemia (Tables 2, 3, and 4).

\section{Body weight}

Hypoxia significantly reduced body weight of aged mice (Fig. IA). In response to the initiation of the experiment, hypoxic mice showed a reduced food intake (Fig. IB). However, after approximately 9 days, food intake was normalized to that of normoxic animals and body weight loss after 21 days of hypoxia was significantly stronger in the hypoxic than in the pair-fed aged mice $(P=0.002$; Fig. IA). Together, these data reveal a food intake-independent effect of hypoxia on body weight.

\section{Fat pad and muscle weights and muscle fiber cross-sectional area}

Hypoxia-associated body weight loss was reflected by hypoxiainduced reductions of fat pad (Fig. IC) and muscle weights (Fig. ID); this loss was only partly dependent on the reduced food intake.

Whereas soleus showed a discrepancy between muscle weight and fiber cross-sectional area in the aged mice (Fig. ID and E), EDL mean fiber cross-sectional area (Fig. IF) closely resembled the changes in EDL muscle weight (Fig. ID). The fibers in the EDL seemed most affected by hypoxia, with no additional effect of reduced food intake. In the soleus, food intake appears to have a larger role in atrophy, although changes between pair-fed and normoxia are not significant, except for type I/Ila and IIx/b fibers. Overall, hypoxia thus affected muscle fiber cross-sectional area in both a food intakedependent and -independent manner. 
TABLE I. Primer sequences used for RT-qPCR

\begin{tabular}{|c|c|c|c|c|c|}
\hline Symbol & Name & Ensembl ID & Forward primer $\left(5^{\prime} \rightarrow 3^{\prime}\right)$ & Reverse primer $\left(5^{\prime} \rightarrow 3^{\prime}\right)$ & $\begin{array}{l}\text { Amplicon } \\
\text { size (bp) }\end{array}$ \\
\hline Axin $I$ & Axin 1 & ENSMUSG00000024I82 & AGTGGATCATTGAGGGAGAGA & GCCCCAGGACGCTCGAT & 124 \\
\hline$B 2 m$ & $\beta$-2-microglobulin & ENSMUSG00000060802 & CTTTCTGGTGCTTGTCTCACTGA & GTATGTTCGGCTTCCCATTCTC & 104 \\
\hline Canx & Calnexin & ENSMUSG00000020368 & GCAGCGACCTATGATTGACAACC & GCTCCAAACCAATAGCACTGAAAGG & 170 \\
\hline Cox5a & $\begin{array}{l}\text { Cytochrome c oxidase } \\
\text { subunit } \mathrm{Va}\end{array}$ & ENSMUSG00000000088 & TGCGAGCATGTAGACCGTTAAAT & GAGGTCCTGCTTTGTCCTTAACA & 77 \\
\hline Cycl & Cytochrome c-I & ENSMUSG0000002255I & GCATTCGGAGGGGTTTCCAG & CCGCATGAACATCTCCCCA & 176 \\
\hline Esrra & $\begin{array}{l}\text { Estrogen-related } \\
\text { receptor alpha }\end{array}$ & ENSMUSG00000024955 & GGCGGACGGCAGAAGTACAAA & GCGACACCAGAGCGTTCAC & 130 \\
\hline Gabpa & $\begin{array}{l}\text { GA binding protein } \\
\text { alpha; nuclear } \\
\text { respiratory factor } 2 \\
\text { alpha }\end{array}$ & ENSMUSG00000008976 & TGCTGCACTGGAAGGCTACA & TTACCCAAACCACCCAATGC & 104 \\
\hline$m t-C_{02}$ & $\begin{array}{l}\text { Cytochrome c oxidase } \\
\text { subunit II }\end{array}$ & ENSMUSG00000064354 & CCATCCCAGGCCGACTAA & ATTTCAGAGCATTGGCCATAGAA & 76 \\
\hline Myhl & $\begin{array}{c}\text { Myosin heavy chain I } \\
\text { (type IIx isoform) }\end{array}$ & ENSMUSG00000056328 & GACAAACTGCAATCAAAGG & TTGGTCACTTTCCTGCACTT & 231 \\
\hline Myh2 & $\begin{array}{c}\text { Myosin heavy chain } 2 \\
\text { (type lla isoform) }\end{array}$ & ENSMUSG00000033196 & CGATGATCTTGCCAGTAATG & ATAACTGAGATACCAGCG & 221 \\
\hline Myh4 & $\begin{array}{c}\text { Myosin heavy chain } 4 \\
\text { (type llb isoform) }\end{array}$ & ENSMUSG00000057003 & AGGGCGGCGGTGGAA & TGGGAATGAGGCATCTGACAA & 141 \\
\hline Myh7 & $\begin{array}{l}\text { Myosin heavy chain } 7 \\
\text { (type I isoform) }\end{array}$ & ENSMUSG00000053093 & CAGATCGGGAGAATCAGTCCAT & AGCAAAATATTGGATGACCCTCTTA & 89 \\
\hline Ndufb3 & $\begin{array}{l}\text { NADH dehydrogenase } \\
\text { (ubiquinone) I beta } \\
\text { subcomplex } 3\end{array}$ & ENSMUSG00000026032 & ACAGACAGTGGAAAATTGAAGGG & GCCCATGTATCTCCAAGCCT & 110 \\
\hline Nrfl & $\begin{array}{l}\text { Nuclear respiratory } \\
\text { factor I }\end{array}$ & ENSMUSG00000058440 & AGCCACATTGGCTGATGCTT & GGTCATTTCACCGCCCTGTA & 124 \\
\hline Ppara & $\begin{array}{l}\text { Peroxisome } \\
\text { proliferator-activated } \\
\text { receptor alpha }\end{array}$ & ENSMUSG00000022383 & ACTACGGAGTTCACGCATGTG & TTGTCGTACACCAGCTTCAGC & 76 \\
\hline Ppard & $\begin{array}{l}\text { Peroxisome } \\
\text { proliferator-activated } \\
\text { receptor delta }\end{array}$ & ENSMUSG00000002250 & AGGCCCGGAGCATCCTCA & TGGATGACAAAGGGTGCGTTG & 55 \\
\hline Pparg & $\begin{array}{l}\text { Peroxisome } \\
\text { proliferator-activated } \\
\text { receptor gamma }\end{array}$ & ENSMUSG00000000440 & CGGAAGCCCTTTGGTGACTT & TGGGCTTCACGTTCAGCAAG & 148 \\
\hline Ppargcla & $\begin{array}{l}\text { Peroxisome } \\
\text { proliferator-activated } \\
\text { receptor gamma } \\
\text { coactivator I alpha }\end{array}$ & ENSMUSG000000029167 & CAACAATGAGCCTGCGAACA & CTTCATCCACGGGGAGACTG & 104 \\
\hline Ppargclb & $\begin{array}{l}\text { Peroxisome } \\
\text { proliferator-activated } \\
\text { receptor gamma } \\
\text { coactivator I beta }\end{array}$ & ENSMUSG0000003387I & ACCCTGAGAAAGCGCAATGA & CCCAGATGAGGGAAGGGACT & 120 \\
\hline Ppia & $\begin{array}{l}\text { Peptidyl-prolyl cis-trans } \\
\text { isomerase A; } \\
\text { Cyclophilin A }\end{array}$ & ENSMUSG0000007/866 & TTCСТССТTTCACAGAATTATTCCA & CCGCCAGTGCCATTATGG & 75 \\
\hline Rn/8s & I8S ribosomal RNA & ${ }^{*}$ RefSeq NR_003278.I & AGTTAGCATGCCAGAGTCTCG & TGCATGGCCGTTCTTAGTTG & 76 \\
\hline$R_{p}$ & $\begin{array}{l}\text { Large ribosomal } \\
\text { protein P0 }\end{array}$ & JSG00000067274 & G & ATGG & 85 \\
\hline Sdhb & $\begin{array}{l}\text { Succinate } \\
\text { dehydrogenase } \\
\text { complex, subunit B }\end{array}$ & ENSMUSG00000009863 & AATTTGCCATTTACCGATGGGA & AGCATCCAACACCATAGGTCC & 104 \\
\hline Tfam & $\begin{array}{l}\text { Mitochondrial } \\
\text { transcription } \\
\text { factor A }\end{array}$ & ENSMUSG00000003923 & CCGGCAGAGACGGTTAAAAA & TCATCCTTTGCCTCCTGGAA & 129 \\
\hline Tubala & Tubulin, alpha IA & ENSMUSG00000072235 & CGTAGACCTGGAACCCACGGT & TGCCTGTGATGAGCTGCTCA & 86 \\
\hline
\end{tabular}

*No existing Ensembl ID.

Muscle fiber-type composition and fiber-specific myosin heavy chain (MyHC) expression in skeletal muscle

Hypoxia increased soleus hybrid type I/lla fiber proportion (Fig. 2A). On the level of gene expression, the hypoxic aged mice showed decreased MyHC type Ilb in the soleus (Fig. 2C) and increased MyHC type I in the EDL (Fig. 2D).

\section{Metabolic enzyme activities in skeletal muscle}

Phosphofructokinase (PFK) activity was significantly increased by hypoxia in the soleus (Fig. 3A) and EDL (Fig. 3B) of aged mice. The aged hypoxic mice showed a slight reduction of citrate synthase (CS) activity in the EDL (Fig. 3B) but no change in cytochrome $c$ oxidase (COX) activity (Fig. $3 A$ and $B$ ).
Changes in 3-hydroxyacyl-CoA dehydrogenase (HAD) activity were non-significant.

Protein and gene expression levels of mitochondrial components

To assess whether reduced citrate synthase activity was associated with a reduced mitochondrial content, we measured protein content of five subunits of the oxidative phosphorylation (OXPHOS) chain. There was generally no sign of repressed content of these subunits in soleus (Fig. 3C; a representative blot is included in Supplemental Figure SI), nor in EDL (Fig. 3D) of aged hypoxic mice. In contrast, gene expression levels of some $\mathrm{OXPHOS}$ subunits were repressed (Fig. $3 \mathrm{E}$ and $\mathrm{F}$ ). These changes were sometimes partly caused by the reduced food intake. 
TABLE 2. Arterial blood gas analysis and hematological adaptations in aged (52 week old) mice

\begin{tabular}{|c|c|c|c|}
\hline & Normoxia & Pair-fed & Hypoxia \\
\hline \multicolumn{4}{|l|}{ Arterial blood gas analysis } \\
\hline $\mathrm{pH}$ & $7.28(7.25,7.30)$ & $7.35(7.30,7.37)^{*}$ & $7.10(7.06,7.16)^{. * \#}$ \\
\hline $\mathrm{PaO}_{2}, \mathrm{mmHg}$ & 129.5 (I20.4, I39.1) & $133.7(128.6,136.5)$ & $33.8(33.3,34.4)$ \\
\hline $\mathrm{PaCO}_{2}, \mathrm{mmHg}$ & $36.2(28.1,4 \mid .0)$ & $29.0(28.3,34.3)$ & $35.5(31.3,37.6)$ \\
\hline $\mathrm{HCO}_{3}{ }^{-}, \mathrm{mM}^{\circ}$ & $16.3(13.2,18.4)$ & $16.5(16.1,18.1)$ & $10.4(9.4,12.0)^{\text {:H }}$ \\
\hline $\mathrm{SaO}_{2}, \%$ & $101(100,101)$ & $102(101,102)$ & $24(19,27)$ \\
\hline Base excess, $\mathrm{mEqL}^{-1}$ & $-9.9(-11.7,-7.6)$ & $-7.2(-8.5,-7.0)$ & $-22.6(-24.0,-17.7)$ \\
\hline \multicolumn{4}{|l|}{ Hematological adaptations } \\
\hline Hematocrit, \% & $0.46(0.44,0.47)$ & $0.45(0.44,0.47)$ & $0.76(0.74,0.78)$ \\
\hline Hemoglobin, mM & $9.0(8.6,9.5)$ & $8.7(8.2,9.3)$ & I 4.5 (14.2, I 14.7) \\
\hline Erythrocytes, $\times 10^{6}$ & $10.0(9.4,10.0)$ & $9.7(9.5,10.2)$ & $13.5(13.3,13.8)$ \\
\hline MCV, fL & $45.8(45.7,46.1)$ & $46.3(45.8,46.9)$ & $55.3(54.7,58.4)$ \\
\hline $\mathrm{MCH}, \mathrm{pg}$ & $0.91(0.89,0.92)$ & $0.89(0.88,0.91)$ & $1.08(1.02,1.10)^{*}$ \\
\hline $\mathrm{MCHC}, \mathrm{g} \mathrm{dl}^{-1}$ & $20.0(19.3,20.2)$ & $19.1(18.5,19.7)$ & $19.1(18.3,19.6)$ \\
\hline p50 (a) & $29.6(28.7,30.9)$ & $27.6(26.8,29.0)$ & $50.8(49.9,51.6)$ \\
\hline Spleen $(\mathrm{g})$ & $80.6(66.1,90.3)$ & $82.7(77.6,92.6)$ & $215.1(159.7,238.9)^{*}$ \\
\hline
\end{tabular}

$\mathrm{MCV}$, mean corpuscular volume; $\mathrm{MCH}$, mean corpuscular hemoglobin; $\mathrm{MCHC}$, mean corpuscular hemoglobin concentration.

Values are median (25th percentile, 75th percentile). Blood gas data were available for six normoxic, seven pair-fed, and six hypoxic mice.

${ }^{*} P<0.05$ compared to normoxic mice.

${ }^{\#} P<0.05$ compared to pair-fed mice. Data partly overlap with our previous study (van den Borst et al., 2013a).

TABLE 3. Arterial blood gas analysis and hematological adaptations in young (4 week old) mice

\begin{tabular}{|c|c|c|c|}
\hline & Normoxia & Pair-fed & Hypoxia \\
\hline \multicolumn{4}{|l|}{ Arterial blood gas analysis } \\
\hline $\mathrm{pH}$ & $7.31(7.26,7.34)$ & $7.31(7.26,7.33)$ & $7.16(7.09,7.19)$ \\
\hline $\mathrm{PaO}_{2}, \mathrm{mmHg}$ & $134.9(132.1,150.6)$ & |35.6 (I31.I, I38.4) & $41.9(37.8,43.1)$ \\
\hline $\mathrm{PaCO}_{2}, \mathrm{mmHg}$ & $23.3(22.5,32.3)$ & $30.5(26.4,33.0)$ & $28.0(23.7,29.0)$ \\
\hline $\mathrm{HCO}_{3}{ }^{-}, \mathrm{mM}$ & $12.4(11.2,13.9)$ & $14.9(12.9,16.3)$ & $8.6(7.6,10.4)$ \\
\hline $\mathrm{SaO}_{2}, \%$ & $101(101,102)$ & $101(100,101)$ & $33(27,37)$ \\
\hline Base excess, $\mathrm{mEq}^{-1}$ & $-12.5(-13.3,-11.3)$ & $-10.2(-11.7,-8.6)$ & $-21.8(-25.7,-18.0)$ \\
\hline \multicolumn{4}{|l|}{ Hematological adaptations } \\
\hline Hematocrit, \% & $0.36(0.35,0.36)$ & $0.37(0.36,0.39)$ & $0.64(0.61,0.65)$ \\
\hline Hemoglobin, mM & $7.9(7.8,8.0)$ & $8.4(8.0,8.8)$ & $13.8(13.1,13.9)$ \\
\hline Erythrocytes, $\times 10^{6}$ & $8.6(8.4,8.8)$ & $9.0(8.7,9.3)$ & I3.I (I2.7, I3.3) \\
\hline $\mathrm{MCV}, \mathrm{fL}$ & $4 I .3(4 I .0,4 I .6)$ & $4 I .4(4 I .1,42.0)$ & $48.2(47.8,49.3)$ \\
\hline $\mathrm{MCH}, \mathrm{pg}$ & $0.92(0.91,0.92)$ & $0.93(0.91,0.94)$ & $1.03(1.02,1.04)$ \\
\hline $\mathrm{MCHC}, \mathrm{gdl}^{-1}$ & $22.3(21.9,22.4)$ & $22.3(22.1,22.4)$ & $21.3(21.2,21.6)$ \\
\hline p50 (a) & $28.3(27.4,30.2)$ & $28.7(28.0,30.1)$ & $53.3(49.7,56.6)$ \\
\hline Spleen (g) & $69.1(67.5,71.9)$ & $51.8(50.2,57.3)$ & $73.2(63.5,86.1)^{\#}$ \\
\hline
\end{tabular}

$\mathrm{MCV}$, mean corpuscular volume; $\mathrm{MCH}$, mean corpuscular hemoglobin; $\mathrm{MCHC}$, mean corpuscular hemoglobin concentration.

Values are median (25th percentile, 75th percentile). Blood gas data were available for six normoxic, eight pair-fed, and eight hypoxic mice.

$P<0.05$ compared to normoxic mice.

${ }^{\#} P<0.05$ compared to pair-fed mice.

TABLE 4. Arterial blood gas analysis and hematological adaptations in adult ( 12 week old) mice

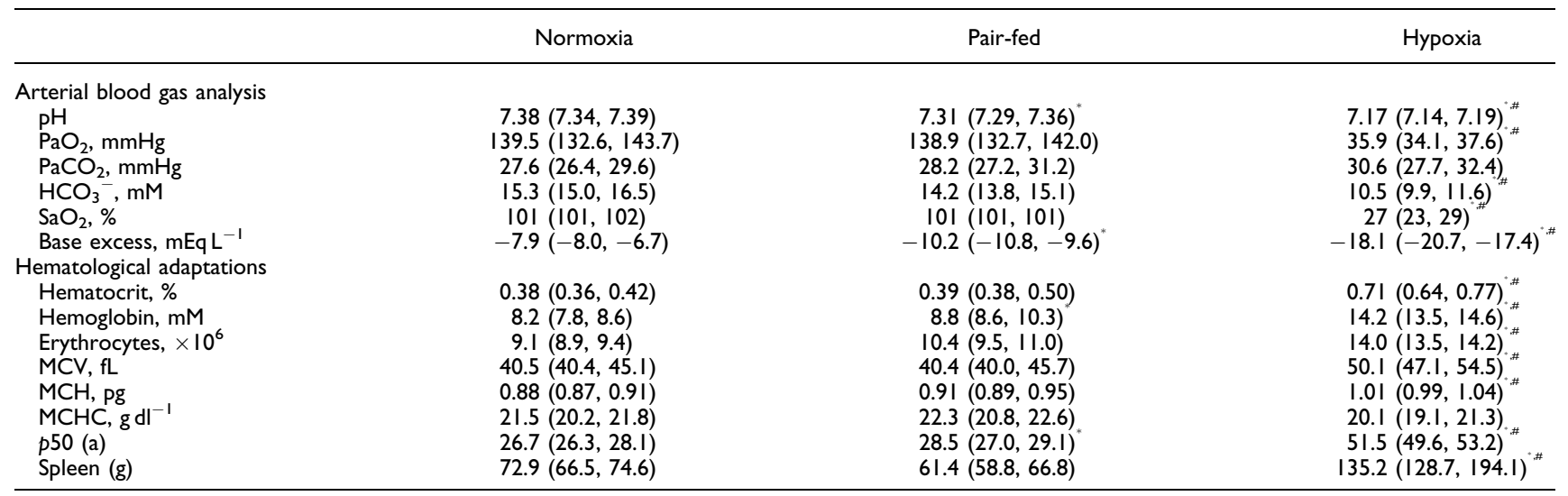

$\mathrm{MCV}$, mean corpuscular volume; $\mathrm{MCH}$, mean corpuscular hemoglobin; $\mathrm{MCHC}$, mean corpuscular hemoglobin concentration. Values are median (25th percentile, 75th percentile). Blood gas data were available for seven normoxic, seven pair-fed, and eight hypoxic mice. " $P<0.05$ compared to normoxic mice.

${ }^{\#} P<0.05$ compared to pair-fed mice. 

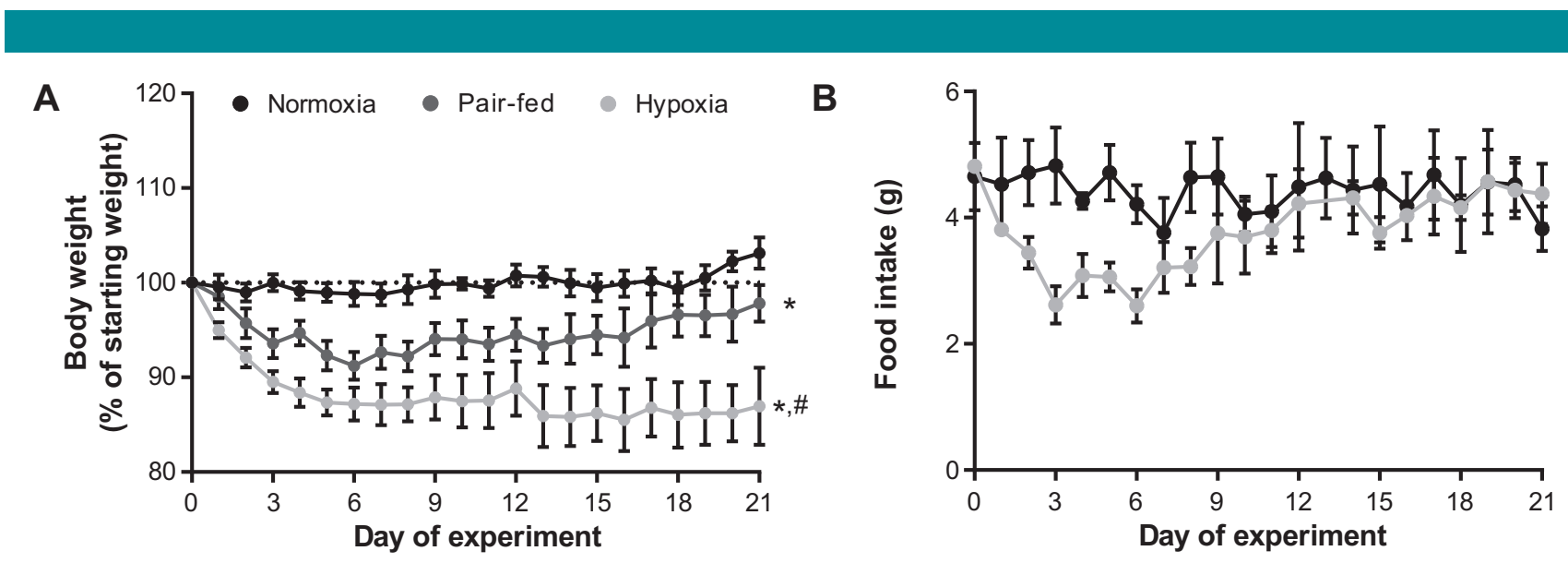

C

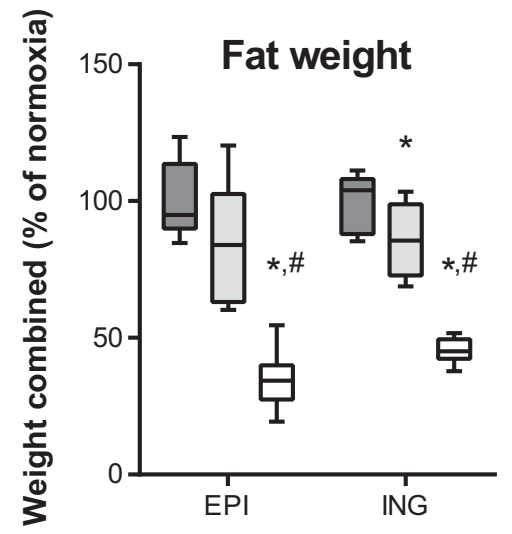

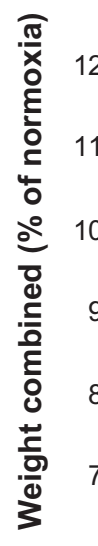

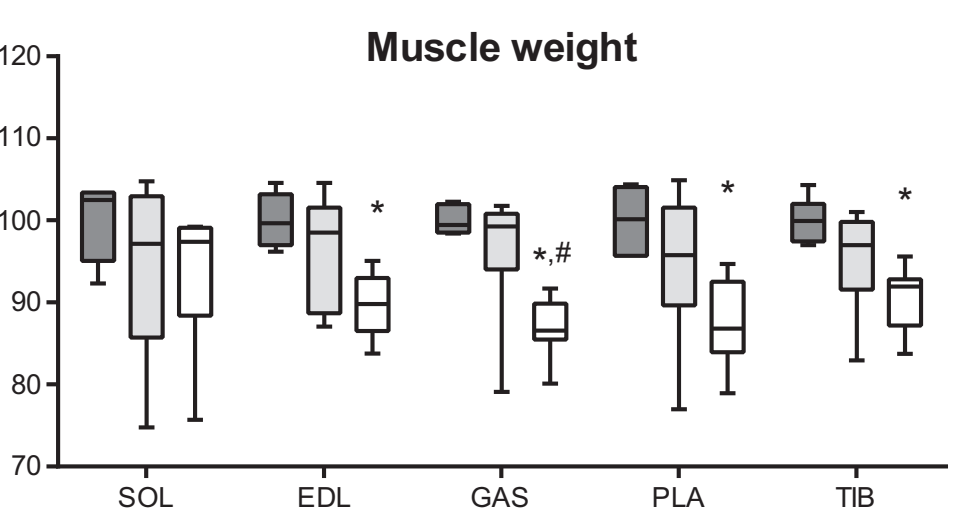

E

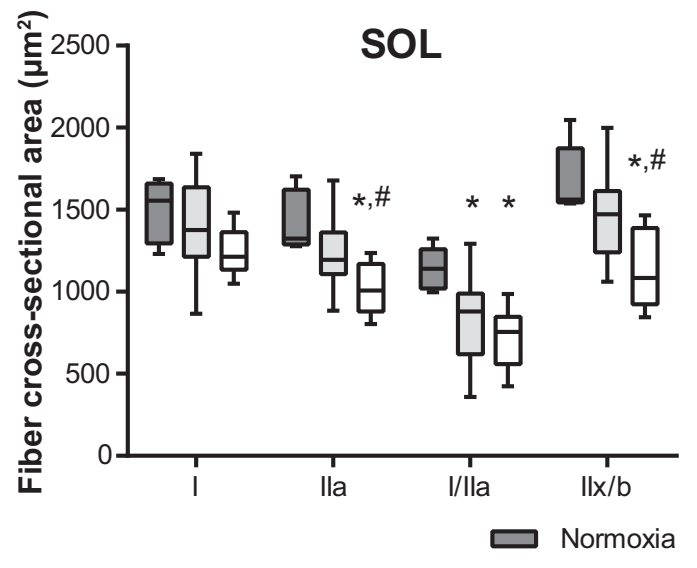

$\mathbf{F}$

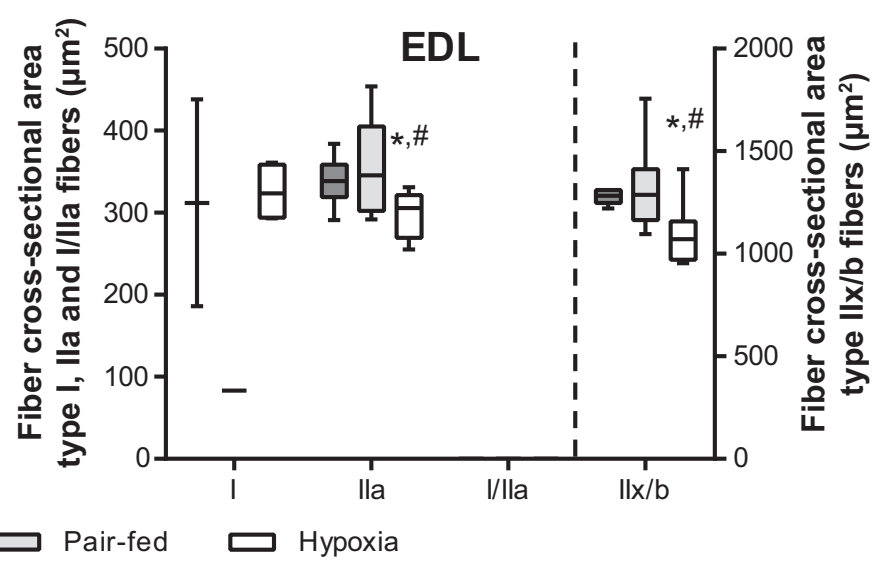

Fig. I. Aged mice exposed to hypoxia develop cachexia, which is only partly explained by reduced food intake. A: Body weight as percentage of starting weight (mean \pm SD). Significance indicated for comparison on day 21 . B: Food intake was determined per cage and averaged over the number of mice in the cage (mean \pm SD). C: Paired fat weight of both fat pads per animal. EPI, epididymal fat pad; ING, inguinal fat pad. D: Paired muscle weight of both muscles per animal. SOL, soleus; EDL, extensor digitorum longus; GAS, gastrocnemius; PLA, plantaris; TIB, tibialis anterior. E-F: Fiber-type specific cross-sectional areas in the soleus (E) and EDL (F). Number of animals per group: normoxic $n=6$, pair-fed $n=8$, hypoxic $n=8$, except in panel C: normoxic $n=5$. Box plots indicate median and interquartile range, whiskers indicate minimum and maximum. Level of significance: ${ }^{*} P<0.05$ compared to normoxic mice, ${ }^{\#} P<0.05$ compared to pair-fed mice. Data in panels A-D partly overlap with our previous study (van den Borst et al., 2013 a).

\section{Expression of key regulators of muscle oxidative} phenotype in skeletal muscle

Because gene expression of some of the OXPHOS subunits was repressed by hypoxia, we measured gene expression levels of important regulators of oxidative phenotype. Expression of PGC-I $\alpha$, PGC-I $\beta$, and ERR $\alpha$ was reduced by hypoxia, but mainly in the soleus of aged mice (Fig. 3G). We could however not detect differences in PGC-I $\alpha$ content (Fig. 3H).
Age-dependent differences in hypoxia effects on body and muscle composition

Age-related differences of hypoxia-associated changes were observed on body weight, fiber-type composition, and OXPHOS gene expression. In response to hypoxia, the aged mice lost body weight, which was still significantly decreased at day 21 compared to the normoxic as well as the pair-fed animals (Fig. IA). In contrast, the body weight of the adult 
A
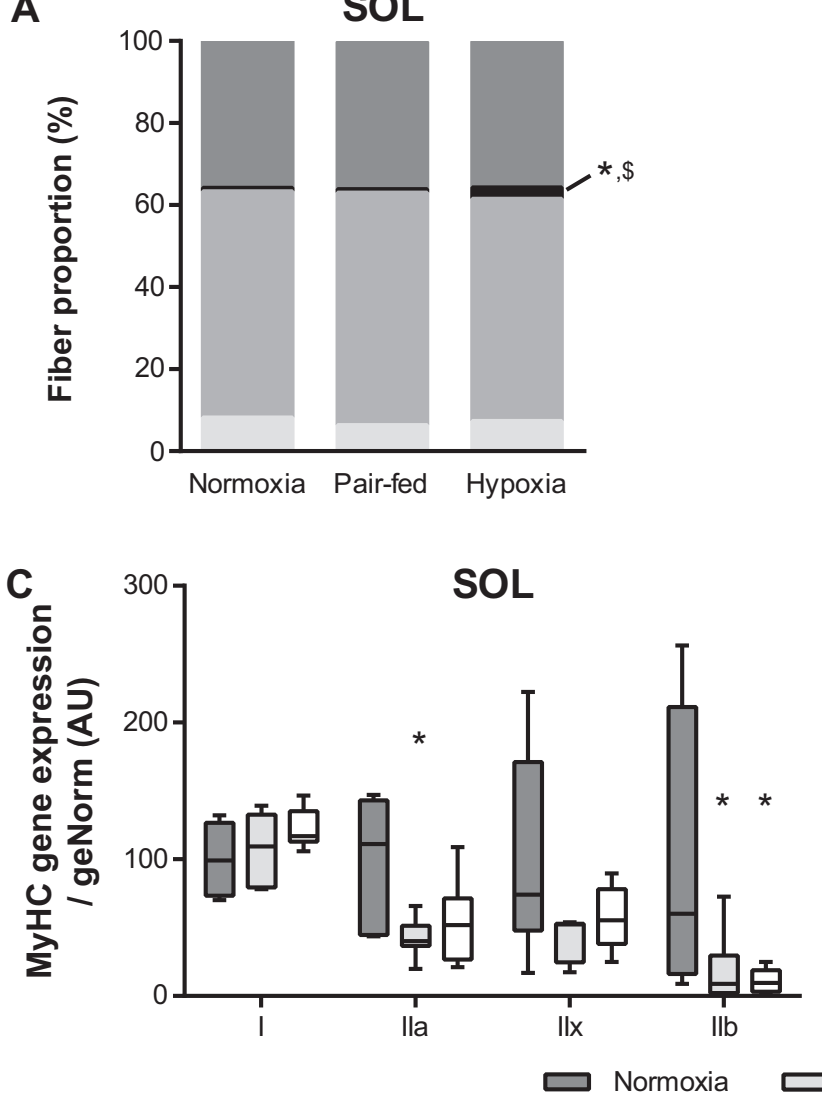

B
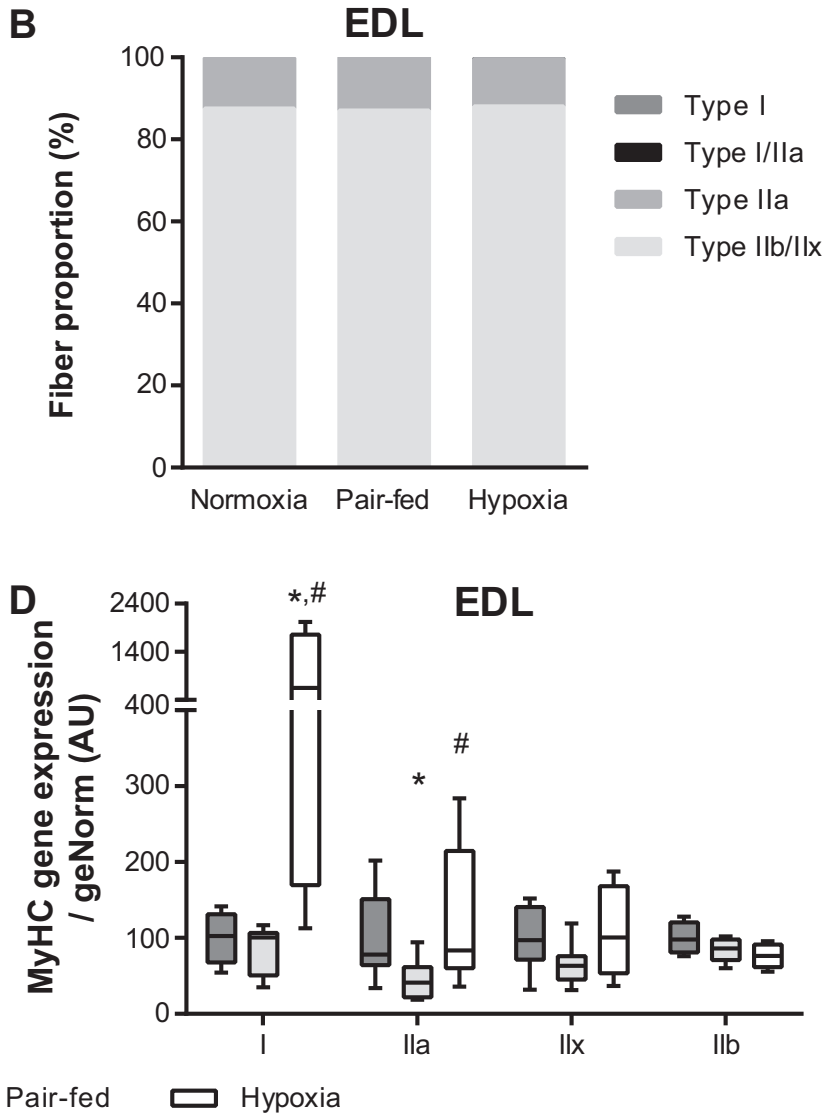

Fig. 2. In aged mice, hypoxia increases type I/Ila hybrid fiber proportion. A-B: Fiber-type composition in the soleus (A) and EDL (B). C-D: Myosin heavy chain gene expression levels in the soleus (C) and EDL (D). Number of animals per group: normoxic $n=6$, pair-fed $n=8$, hypoxic $n=8$, except in panel A: normoxic $n=5$, panel $C$ : pair-fed $n=7$. Box plots indicate median and interquartile range, whiskers indicate minimum and maximum. Level of significance: ${ }^{*} \boldsymbol{P}<0.05$ compared to normoxic mice, ${ }^{\#} \boldsymbol{P}<0.05$ compared to pair-fed mice.

hypoxic mice had recovered by the end of the experiment (Fig. 4A). The hypoxic young mice had significantly lower body weights by the end of the experiment, but this was not different compared to pair-fed mice (Fig. 5A). In the young mice, reduced body weight appeared to be related to a fooddependent stagnation of growth rather than weight loss as was observed in the aged animals.

Hypoxic mice of all ages showed an increased proportion of hybrid type I/lla fibers in the soleus (Figs. 2, 6, and 7), but in addition the young mice showed a significant decrease of the type lla fiber proportion (Fig. 6A). Furthermore, MyHC type I gene expression was increased in the soleus of young hypoxic mice (Fig. 6C). In summary, hypoxia appears to cause a change in soleus fiber-type distribution in mice of all ages, although a direction can only be discerned in the young mice: the increased hybrid type I/Ila and decreased type II proportions combined with the increased gene expression levels of type I MyHC appear to indicate a fiber shift from type lla fibers towards hybrid type I/lla fibers. The more apparent fiber-type changes in the young mice were in contrast to the hypoxia-associated repression of OXPHOS subunit gene expression, which was generally strongest in the aged hypoxic mice (Figs. 3, 8, and 9).

\section{Protein oxidation of muscle proteins}

To assess whether oxidative stress was increased in the muscle after exposure to hypoxia, we measured protein carbonylation in the soleus and EDL (Fig. I0). There were no significant differences, except for the EDL of 4-week-old mice, where oxidation was significantly lower with pair-feeding and hypoxia. Protein carbonylation in the EDL of 4-week-old mice correlated significantly with COX activity (Fig. IOC).

\section{Discussion}

In this study, we show that 3 weeks of hypoxia only mildlyattenuates muscle oxidative phenotype in mice, whereas muscle weightand fat weight are clearly decreased in a hypoxia-dependent manner. Moreover, hypoxia-associated changes were age-dependent: altered fiber-type composition was most prominent in young mice, whereasaged micespecifically showhypoxia-associated reductions of mitochondrial regulators and components.

In the current study, we aimed to establish the effect of hypoxia on muscle oxidative phenotype in aged mice to be able to translate these findings to patients with COPD and chronic respiratory failure, which predominates in the older population. Hence, we mainly focused on 52-week-old mice in this study. Ishihara et al. (1995) indeed showed that the age of rats exposed to hypoxia affects how hypoxia impacts muscle fiber-type composition. Limb muscles of rats undergo a postnatal shift from glycolytic to oxidative fiber types (Wigston and English, 1992). Hypoxia exposure during this developmental period supposedly inhibits this shift and results in a smaller proportion of oxidative fibers in hypoxic young rats 
A

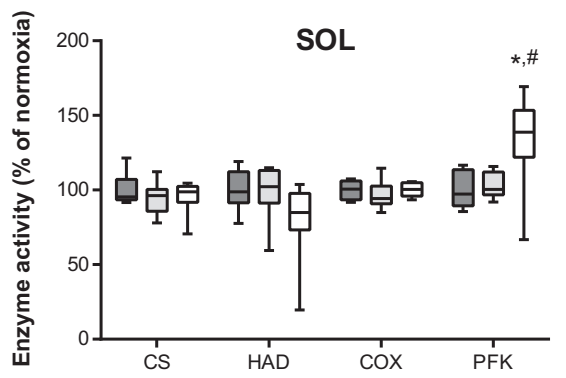

C
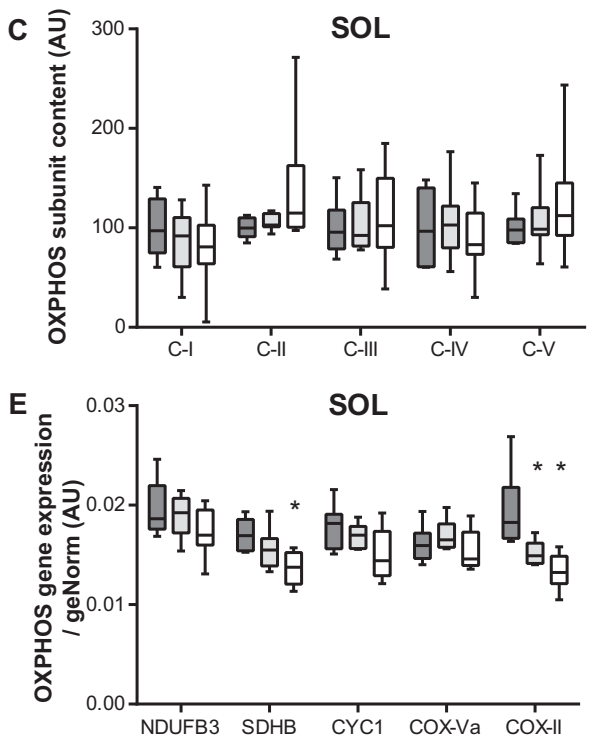

G
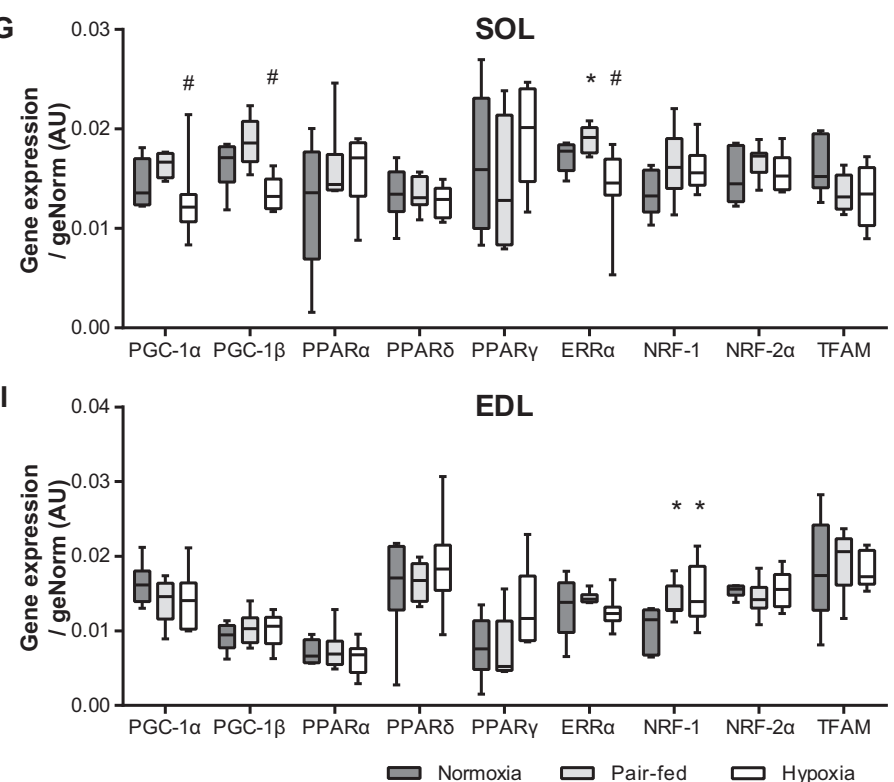

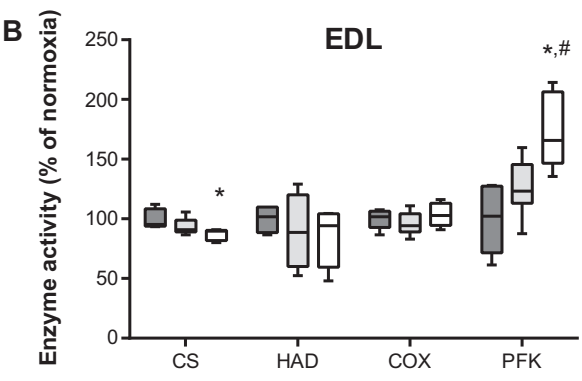

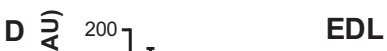
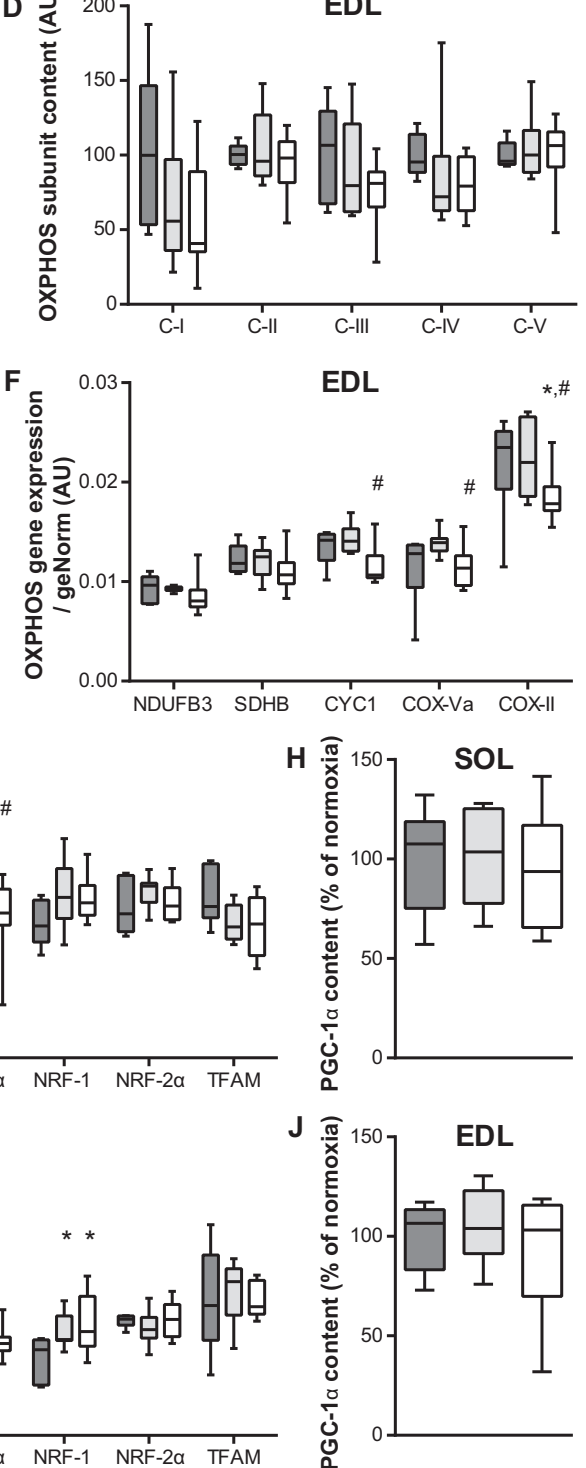

Fig. 3. In aged mice, oxidative capacity is mildly affected by hypoxia. A-B: Metabolic enzyme activity in the soleus (A) and EDL (B). C-D: Protein content of labile subunits of OXPHOS complexes in the soleus (C) and EDL (D). E-F: Gene expression of subunits of OXPHOS complexes in the soleus (E) and EDL (F). G and I: Gene expression of regulators of oxidative metabolism in the soleus (G) and EDL (I). $H$ and J: Protein content of PGC- $\alpha$ in the soleus (H) and EDL (J). CS, citrate synthase; HAD, 3-hydroxyacyl-CoA dehydrogenase; COX, cytochrome c oxidase; PFK, phosphofructokinase. NDUFB3, OXPHOS complex I; SDHB, OXPHOS complex II; CYCI, OXPHOS complex III; COX-Va, OXPHOS complex IV, nuclear encoded; COX-II, OXPHOS complex IV, mitochondrially encoded; PGC-I, PPAR gamma coactivator I; PPAR, peroxisome proliferator-activated receptor; ERR $\alpha$, estrogen-related receptor $\alpha$; NRF, nuclear respiratory factor; Tfam, mitochondrial transcription factor A. Number of animals per group: normoxic $n=6$, pair-fed $n=8$, hypoxic $n=8$, except in panel B, D and J: normoxic $n=5$, panel $B, E$ and $G$ : pair-fed $n=7$. Box plots indicate median and interquartile range, whiskers indicate minimum and maximum. Level of significance: ${ }^{*} \boldsymbol{P}<0.05$ compared to normoxic mice, ${ }^{\#} P<0.05$ compared to pair-fed mice. 

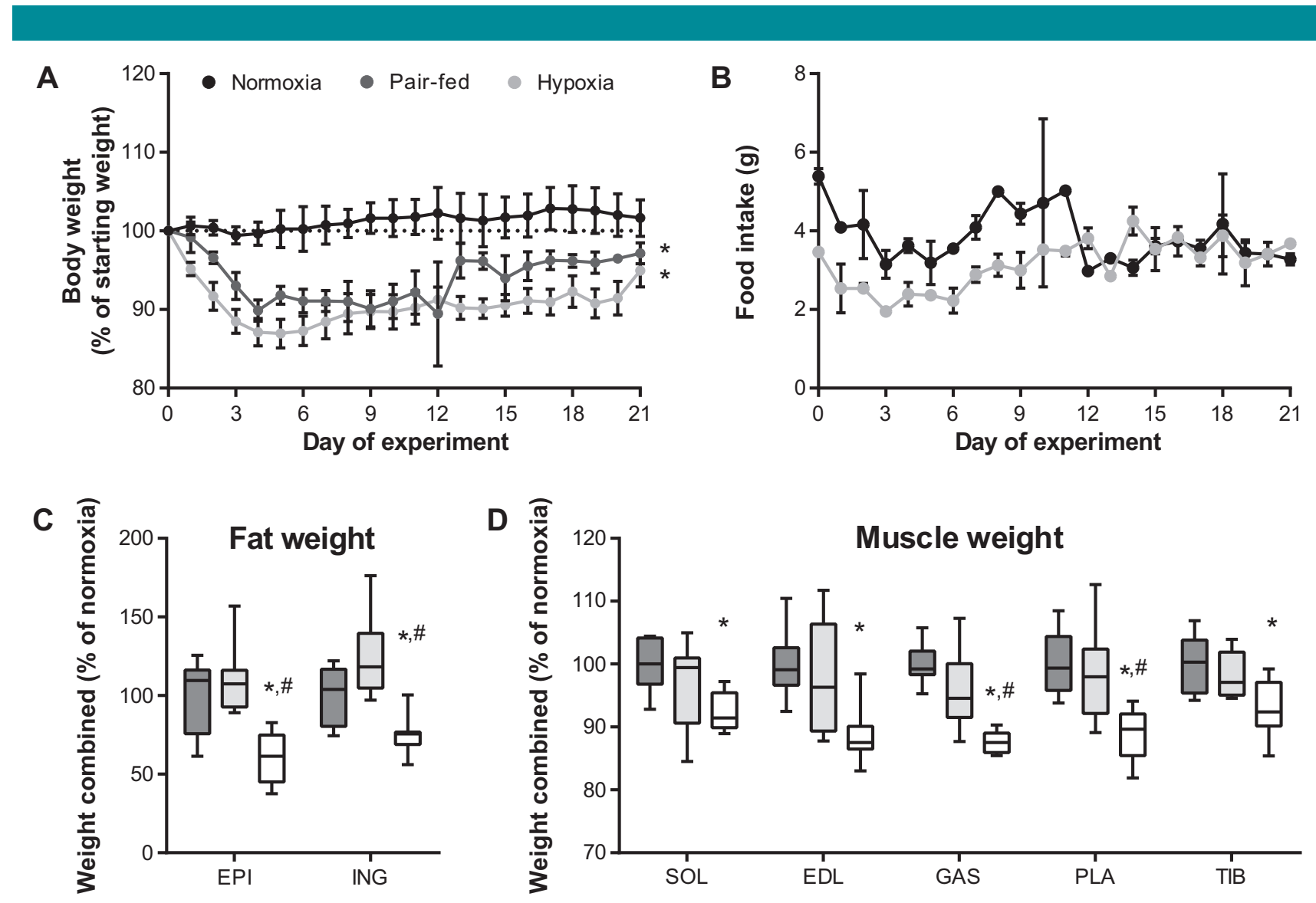

E

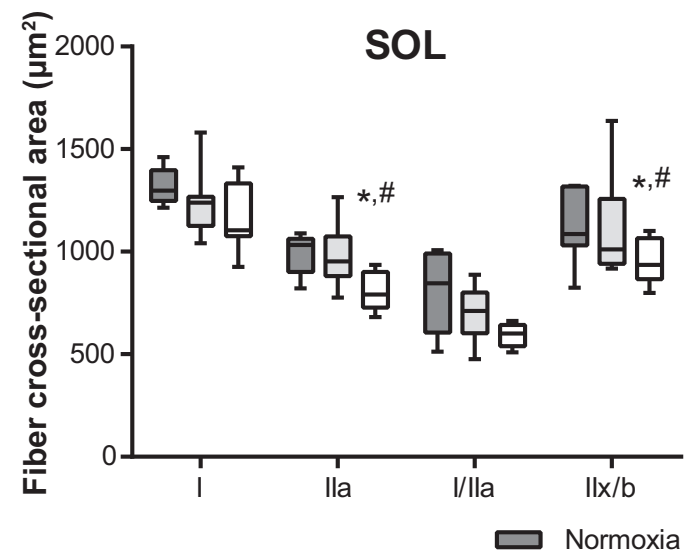

$\mathbf{F}$

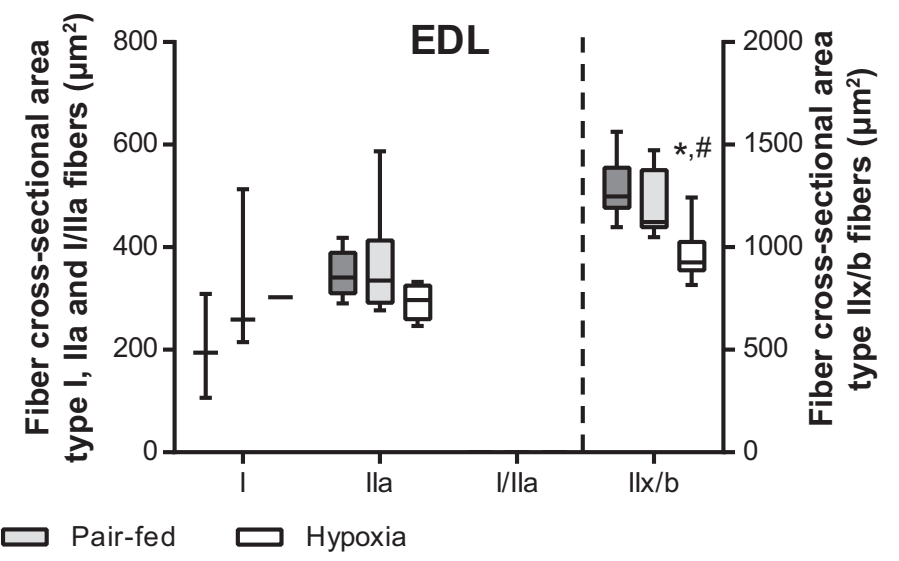

Fig. 4. Adult mice exposed to hypoxia develop cachexia, which is only partly explained by reduced food intake. A: Body weight as percentage of starting weight (mean \pm SD). Significance indicated for comparison on day 21 . B: Food intake was determined per cage and averaged over the number of mice in the cage (mean \pm SD). Note that half of the adult pair-fed mice were accidentally deprived of food on day II and consequently had lower body weight on day 12 . On day I 2, extra food was provided to compensate; this is reflected by the steep weight gain on day 13. C: Paired fat weight of both fat pads per animal. EPI, epididymal fat pad; ING, inguinal fat pad. D: Paired muscle weight of both muscles per animal. SOL, soleus; EDL, extensor digitorum longus; GAS, gastrocnemius; PLA, plantaris; TIB, tibialis anterior. E-F: Fiber-type specific cross-sectional areas in the soleus (E) and EDL (F). Number of animals per group: normoxic $n=8$, pair-fed $n=8$, hypoxic $n=8$, except in panel $E$ and $F$ : normoxic $n=7$, panel $E$ : pair-fed $n=7$. Box plots indicate median and interquartile range, whiskers indicate minimum and maximum. Level of significance: ${ }^{*} \boldsymbol{P}<0.05$ compared to normoxic mice, $\# \boldsymbol{P}<0.05$ compared to pair-fed mice.

(Ishihara et al., 1995). However, Wigston and English (1992) showed that murine postnatal development of the muscle does not include a shift in fiber type towards oxidative fibers.

Therefore, an inhibition of such developmental shift by hypoxia is not to be expected in mice. Nevertheless, we found an effect of age on the hypoxia response, because changes in fiber-type composition were more prominent, albeit still modest, in the youngest mice. This is potentially related to a higher adaptive plasticity of muscle in young compared to old mice, analogous to what has been observed in response to electrical stimulation (Ljubicic et al., 2009) and denervation (O'Leary et al., 20I3).

Interestingly, the young mice exposed to hypoxia appear to shift towards type I/Ila fibers in the soleus, with a concomitant reduction of the proportion of type lla fibers, suggesting co- 

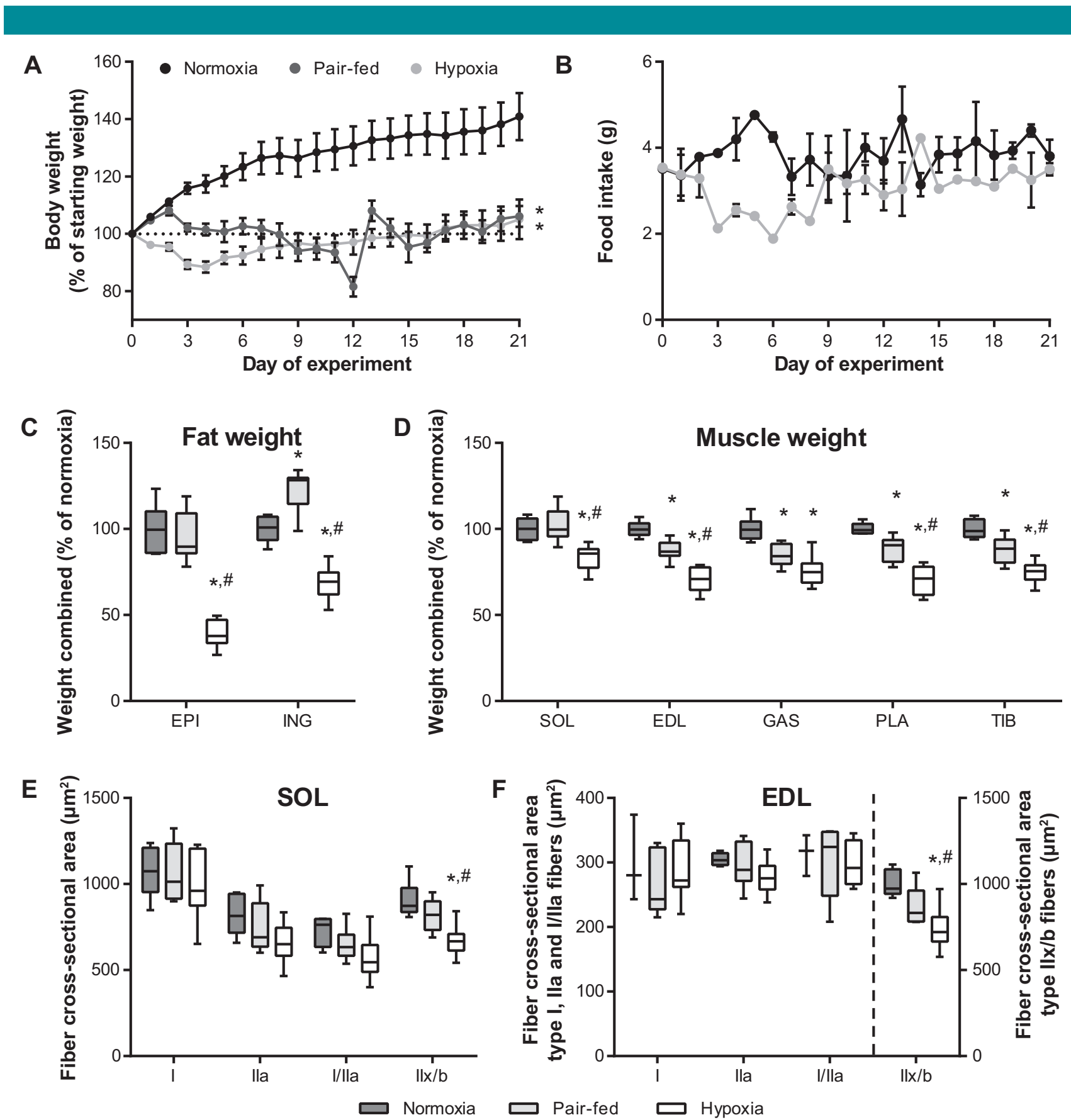

Fig. 5. Young mice exposed to hypoxia show growth stagnation due to hypofagia, but also experience food intake-independent loss of fat and muscle weight. A: Body weight as percentage of starting weight (mean \pm SD). Significance indicated for comparison on day 21 . B: Food intake was determined per cage and averaged over the number of mice in the cage (mean $\pm \mathbf{S D}$ ). Note that all young pair-fed mice were accidentally deprived of food on day $\mathrm{II}$ and consequently had lower body weight on day 12 . On day 12 extra food was provided to compensate; this is reflected by the steep weight gain on day 13. C: Paired fat weight of both fat pads per animal. EPI, epididymal fat pad; ING, inguinal fat pad. D: Paired muscle weight of both muscles per animal. ESOL, soleus; EDL, extensor digitorum longus; GAS, gastrocnemius; PLA, plantaris; TIB, tibialis anterior. E-F: Fiber- type specific cross-sectional areas in the soleus (E) and EDL (F). Number of animals per group: normoxic $n=6$, pair-fed $n=8$, hypoxic $n=9$, except in panel $A$ and F: hypoxic $n=8$, panel $E$ : pair-fed $n=7$, panel F: normoxic $n=5$. Box plots indicate median and interquartile range, whiskers indicate minimum and maximum. Level of significance: ${ }^{*} \boldsymbol{P}<0.05$ compared to normoxic mice, \#P $<0.05$ compared to pair-fed mice.

expression of $\mathrm{MyHC} \mathrm{I} \mathrm{in} \mathrm{lla} \mathrm{fibers.} \mathrm{It} \mathrm{should} \mathrm{be} \mathrm{noted} \mathrm{that} \mathrm{the}$ proportion of type I/Ila fibers is still small (median $4.2 \%$, interquartile range $[1.85 ; 6.34])$. An increase of $\mathrm{MyHC} \mathrm{I}$ expression is, however, in line with our recent in vitro findings, where hypoxia exposure of $\mathrm{C} 2 \mathrm{Cl} 2$ myotubes stimulated the expression of type I MyHC gene and protein (Slot et al., 20I4).
In soleus muscle of mice, it has been shown that type lla fibers have a higher oxidative potential than type I fibers (Bloemberg and Quadrilatero, 20I2). Moreover, Gouspillou et al. (20I4) recently reported on variations in rodent and human muscle fiber types: whereas mouse type lla fibers have a higher mitochondrial content than type $I$, in human muscle type $I$ is 
A

을

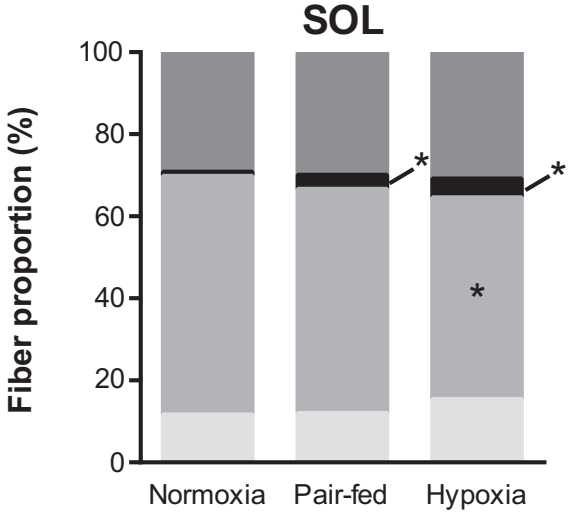

C
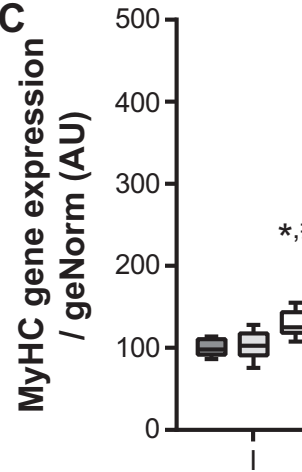

SOL

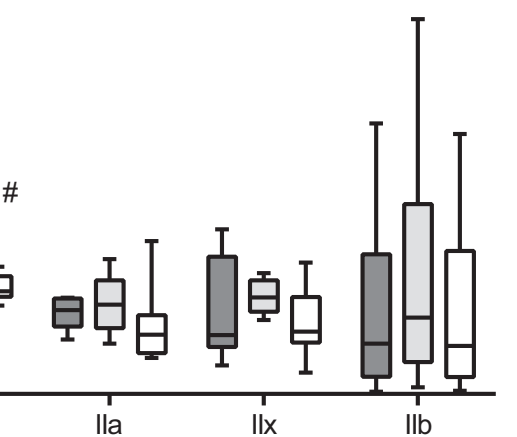

$\square$ Normoxia

B
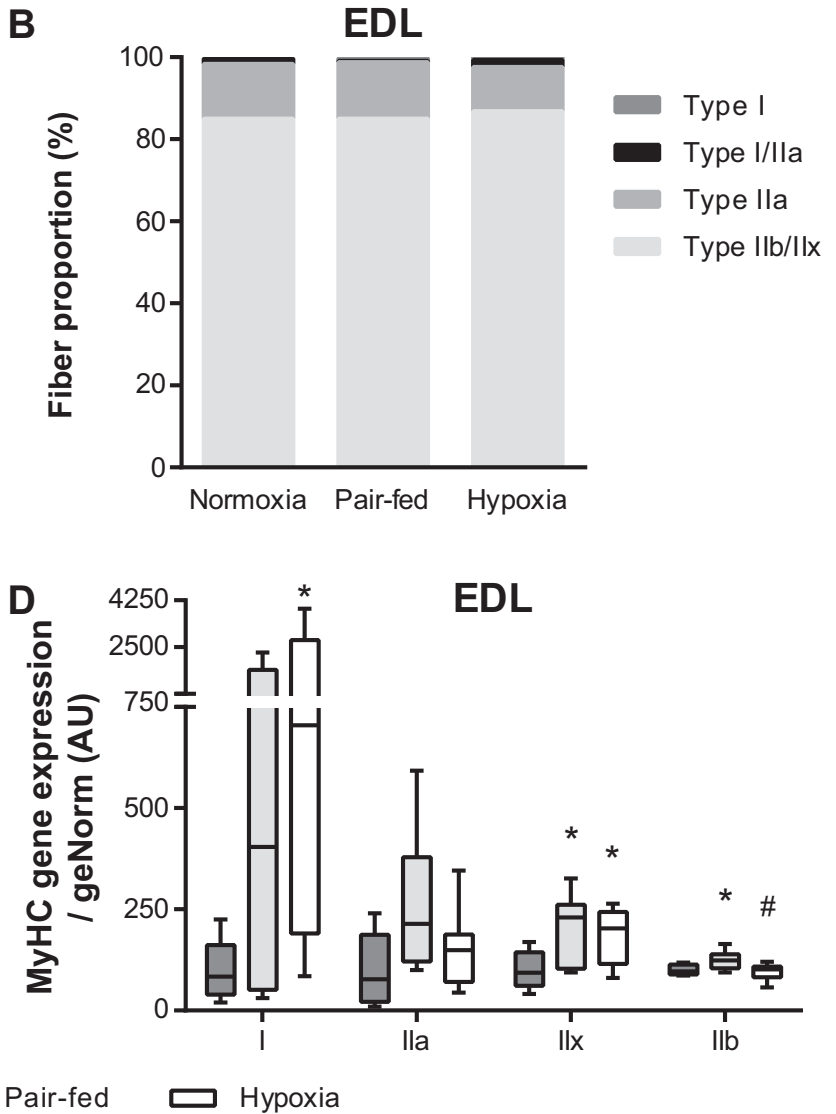

Fig. 6. In young mice, hypoxia appears to shift soleus fiber-type composition from type Ila to type I/Ila hybrid fibers. A-B: Fiber-type composition in the soleus (A) and EDL (B). C-D: Myosin heavy chain gene expression levels in the soleus (C) and EDL (D). Number of animals per group: normoxic $n=6$, pair-fed $n=8$, hypoxic $n=9$, except in panel A: pair-fed $n=7$, panel B: normoxic $n=5$ and hypoxic $n=8$. Box plots indicate median and interquartile range, whiskers indicate minimum and maximum. Level of significance: ${ }^{*} \boldsymbol{P}<0.05$ compared to normoxic mice, \#P 0.05 compared to pair-fed mice.

more enriched in mitochondria than type lla. Therefore, a shift from type lla fibers to type I/lla fibers and/or type Ilx/b fibers in mouse could be adaptive to decrease oxidative phenotype in the muscle in response to reduced oxygen supply. This would be analogous to a type I to II fiber-type shift in the skeletal muscle of COPD patients, where fibers also shift towards less oxidative types. The finding that fiber-type changes appear more prominent in the young mice suggests that hypoxia mainly affects developing muscle fibers and could implicate that hypoxia-associated fiber-type changes occur during the muscle regeneration phase in patients with COPD.

Although the changes in fiber-type composition are associated with decreased citrate synthase activity, no change in protein expression levels of OXPHOS subunits was apparent. In contrast, patients with mild to moderate COPD were shown to have decreased content of several OXPHOS subunits in the quadriceps muscle (van den Borst et al., 20l3b). Possibly, the changes in the hypoxic mice are modest due to the relative short period of hypoxia exposure. Expression of PGC$I \alpha$, PGC-I $\beta$, and ERR $\alpha$, which are important regulators of mitochondrial biogenesis (Wu et al., 1999; Schreiber et al., 2004; Bastin et al., 2008), was repressed in the aged mice. This is in line with the reduced gene expression of OXPHOS subunits in soleus of the aged mice and could indicate that changes were still under way. In line with results in patients with chronic respiratory failure, we found that cytochrome $c$ oxidase (COX) activity was significantly increased in the young hypoxic mice. In the patients, COX activity inversely correlates with arterial oxygen pressure (Sauleda et al., 1998). Altogether, hypoxia-associated changes of muscle Oxphen appear subtle in the mice, which is in line with the modest response of HIF-I signaling in response to hypoxia in human skeletal muscle (Lundby et al., 2009) as well as our recent finding that hypoxiaassociated changes of $\mathrm{OXPHOS}$ and $\mathrm{MyHCl}$ gene expression in vitro were HIF-dependent (Slot et al., 20I4).

Hypoxia stimulated fiber atrophy in both soleus and EDL. Again, age appeared to affect the hypoxia effect, as the strongest decrease of cross-sectional area appeared to occur in the aged mice, but this difference between age groups was not significant (data not shown). Especially the type II fibers were prone to atrophy. This is in line with skeletal muscle of patients with COPD, where atrophy is most pronounced in type II fibers (Gosker et al., 2002a). A sensitivity of glycolytic fibers for hypoxia-associated atrophy has been reported before (de Theije et al., 2015). Hypoxia has been shown to induce expression of myostatin (MSTN) (Hayot et al., 20l I). Moreover, MSTN expression is positively correlated to $\mathrm{MyHC}$ type llb content (Carlson et al., 1999). These two observations may explain why type II fibers are more prone to hypoxiaassociated fiber atrophy. Interestingly, Hayot et al. showed increased MSTN expression in chronic hypoxemic COPD patients as well (Hayot et al., 20l I). 


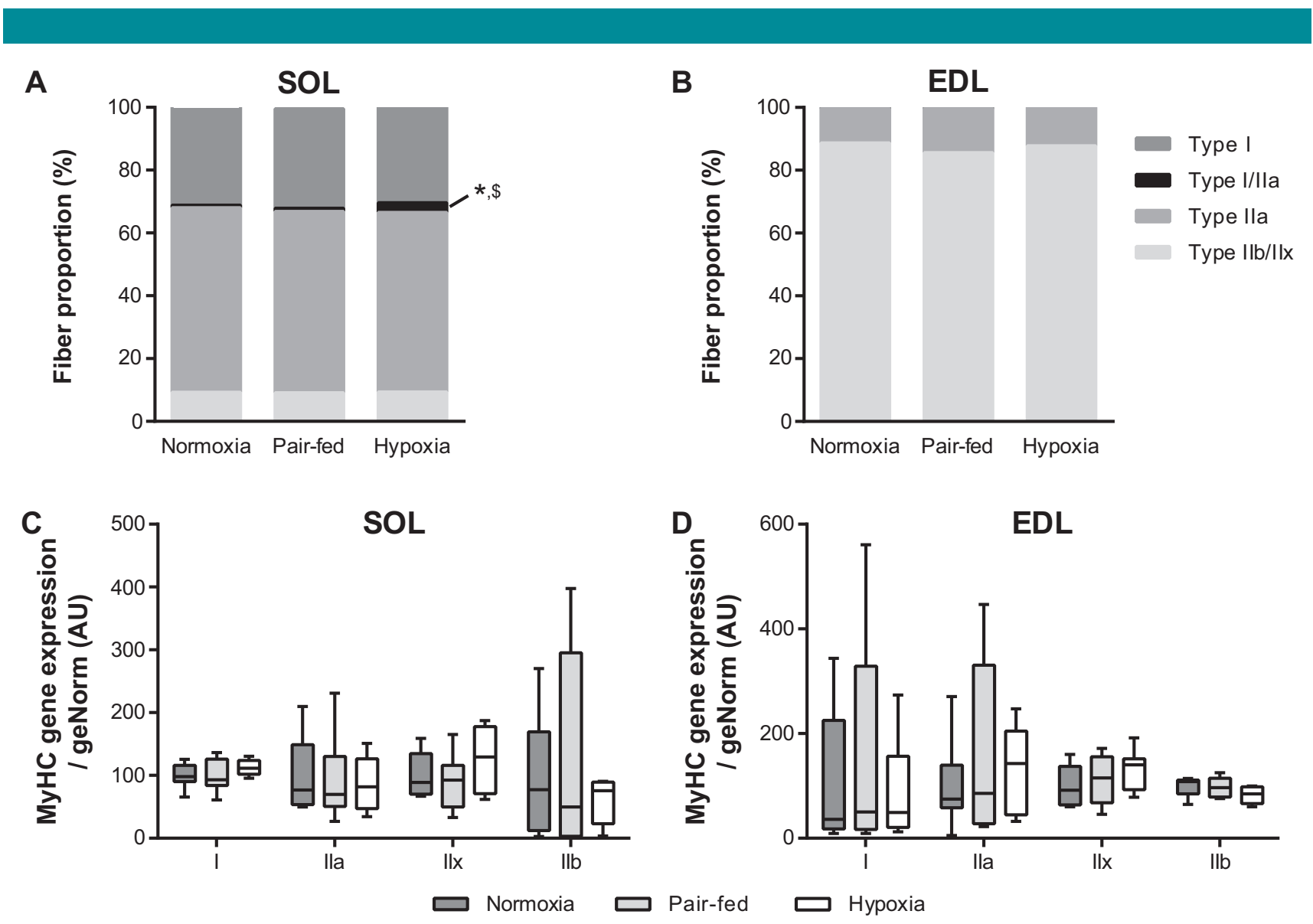

Fig. 7. In adult mice, hypoxia increases type I/lla hybrid fiber proportion. A-B: Fiber-type composition in the soleus (A) and EDL (B). C-D: Myosin heavy chain gene expression levels in the soleus (C) and EDL (D). Number of animals per group: normoxic $n=8$, pair-fed $n=8$, hypoxic $n=8$, except for panels $A$ and B: normoxic $n=7$, panel A: pair-fed $n=7$. Box plots indicate median and interquartile range, whiskers indicate minimum and maximum. Level of significance: ${ }^{*} \boldsymbol{P}<\mathbf{0 . 0 5}$ compared to normoxic mice, $\# \mathbf{P}<0.05$ compared to pair-fed mice.

The difference in muscle weight between normoxic and hypoxic animals was largest in the young mice. Possibly, this is the result of retarded growth rather than increased weight loss. This suggestion is indeed supported by the body weight response, which shows growth retardation rather than weight loss in both pair-fed and hypoxic young mice; the similar body weights in pair-fed and hypoxic mice indicate that growth retardation occurred mainly due to reduced food intake and not due to hypoxia per se. In the adult mice, reduced food intake was also the main reason for loss of body weight. However, in the aged mice hypoxia had an additive effect to reduced food intake on the body weight loss, which suggests that aged mice are more susceptible to hypoxia-associated weight loss. Interestingly, weights of the epididymal and inguinal fat depots in the hypoxic mice were significantly reduced compared to those of both pair-fed and normoxic mice. This suggests that fat weight is lost in the hypoxic animals independent of the reduced food intake. Possibly, this is an indication of an altered metabolic rate under influence of hypoxia. Indeed, we recently reported increased expression of oxidative metabolic markers and lipolysis genes in the fat depots in hypoxia-exposed aged mice (van den Borst et al., $20 \mid 3 a$ ). The increased lipolysis could result in more circulating fatty acids that in turn stimulate expression of oxidative type $I$ $\mathrm{MyHC}$ in the muscle, possibly through PPAR $\delta$ which has been shown to shift MyHC content to slower isoforms (Lunde et al., 2007). Moreover, chronic administration of arachidonic acid to aged rats has been shown to increase the number of $\mathrm{MyHCl}$ positive cells and increase the relative content of $\mathrm{MyHCllx}$ while reducing MyHCllb content (Inoue et al., 20I4).

We found that muscle of aged mice was most affected by hypoxia both in terms of markers of oxidative capacity and fiber cross-sectional area. We expected that muscle of young mice would be characterized by a stronger adaptive plasticity, because increasing age has been shown to reduce the amplitude of adaptations in response to stresses such as limb ischemia, chronic electrical stimulation and disuse caused by denervation (Rivard et al., 1999; Rivard et al., 2000; Ljubicic et al., 2009; O'Leary et al., 2013). For example, attenuated hypoxiaassociated induction of VEGF expression has been shown in aged rabbits (Rivard et al., 2000). This was associated with reduced HIF-I activity (Rivard et al., 2000) and is suggested to explain the impairment of angiogenesis in response to ischemia in old compared to young mice and rabbits (Rivard et al., 1999). This could imply that young mice adapt better to hypoxic conditions by improving capillarization, and therefore, can maintain Oxphen status. An impaired capillary adaptability in the aged mice could thus underlie the more pronounced loss of muscle Oxphen observed in these mice.

Another explanation for the stronger effects of hypoxia in the aged mice is accumulation of oxidative stress-derived damage during their life. Postmitotic cells have been shown to be more prone to accumulate oxidative damage (Radak et al., 200I). This damage could make the cells more sensitive to 
A

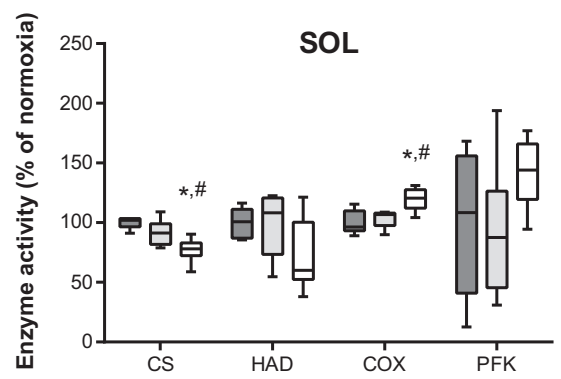

C

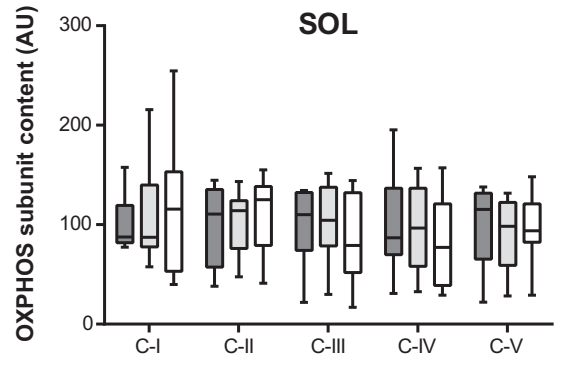

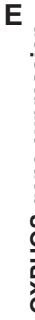

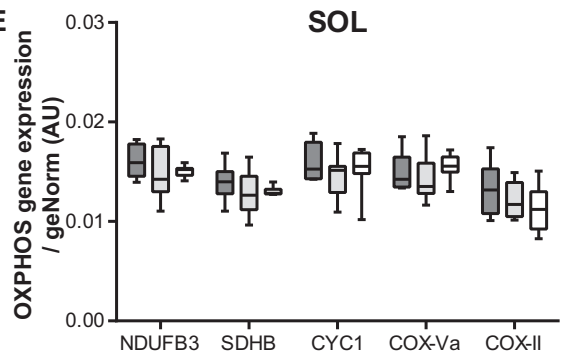

G

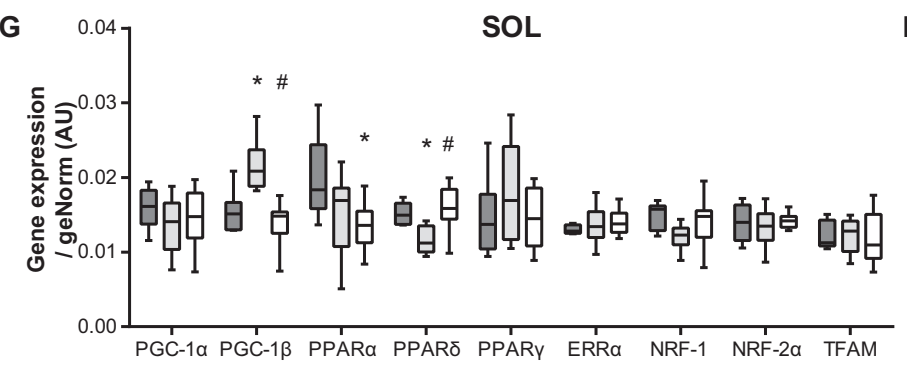

I

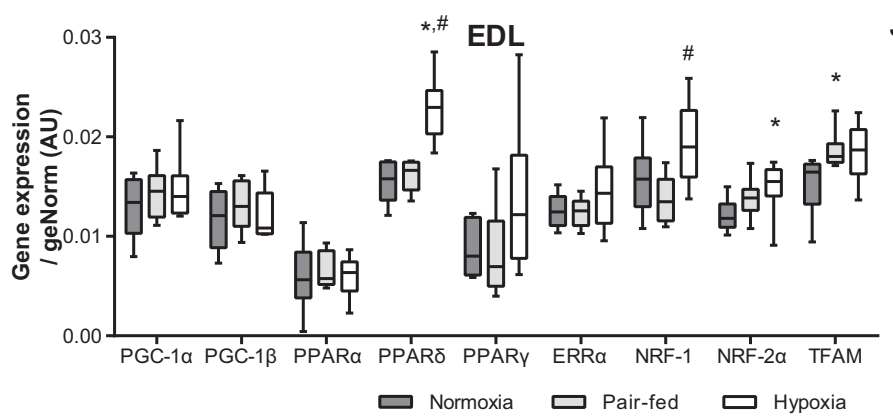

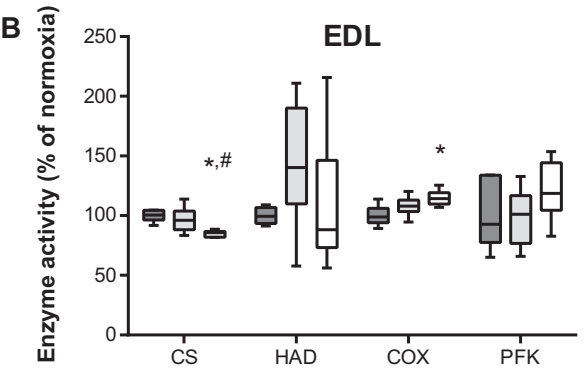
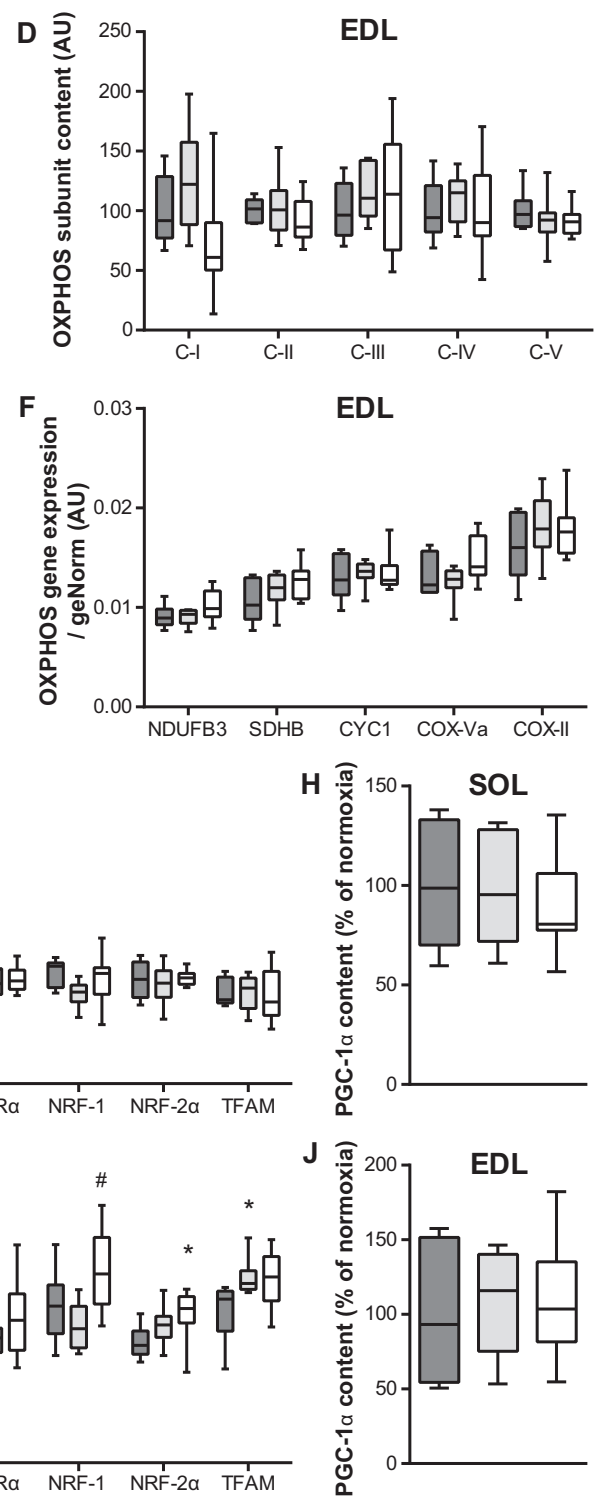

Fig. 8. In young mice, oxidative capacity is only mildly affected by hypoxia. A-B: Metabolic enzyme activity in the soleus (A) and EDL (B). C-D: Protein content of labile subunits of OXPHOS complexes in the soleus (C) and EDL (D). E-F: Gene expression of subunits of OXPHOS complexes in the soleus (E) and EDL (F). G and I: Gene expression of regulators of oxidative metabolism in the soleus (G) and EDL (I). $H$ and J: Protein content of PGC-I $\alpha$ in the soleus (H) and EDL (J). CS, citrate synthase; HAD, 3-hydroxyacyl-CoA dehydrogenase; COX, cytochrome $C$ oxidase; PFK, phosphofructokinase. NDUFB3, OXPHOS complex I; SDHB, OXPHOS complex II; CYCI, OXPHOS complex III; COX-Va, OXPHOS complex IV, nuclear encoded; COX-II, OXPHOS complex IV, mitochondrially encoded; PGC-I, PPAR gamma coactivator I; PPAR, peroxisome proliferator-activated receptor; ERR $\alpha$, estrogen-related receptor $\alpha$; NRF, nuclear respiratory factor; Tfam, mitochondrial transcription factor A. Number of animals per group: normoxic $n=6$, pair-fed $n=8$, hypoxic $n=9$. Box plots indicate median and interquartile range, whiskers indicate minimum and maximum. Level of significance: ${ }^{*} \boldsymbol{P}<0.05$ compared to normoxic mice, \#P 0.05 compared to pair-fed mice. 
A

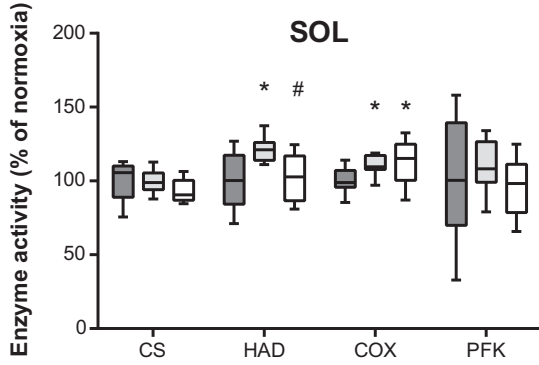

C $\widehat{Q}^{300}{ }^{300}$ SOL

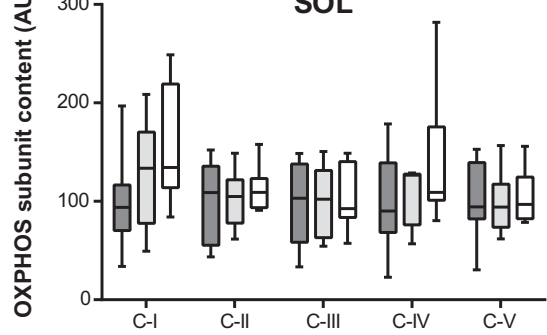

E

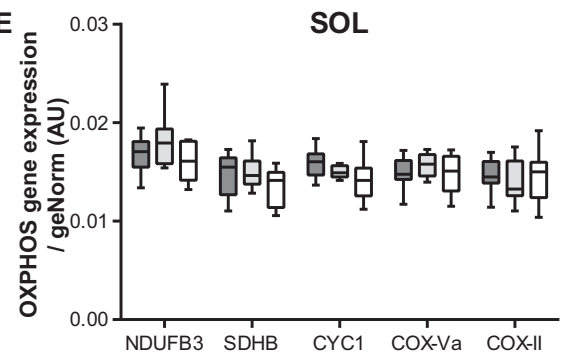

G

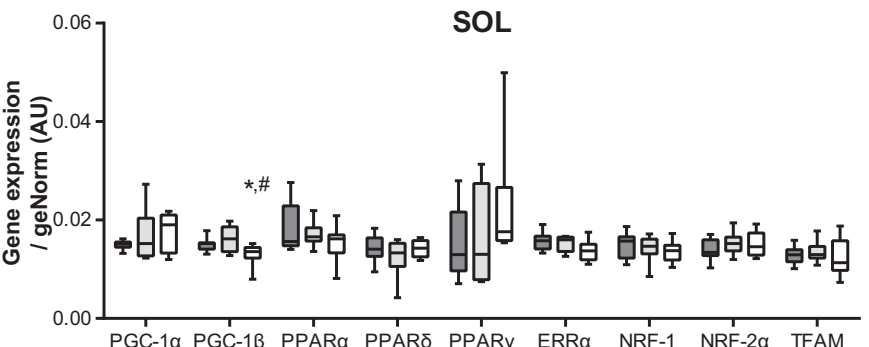

I

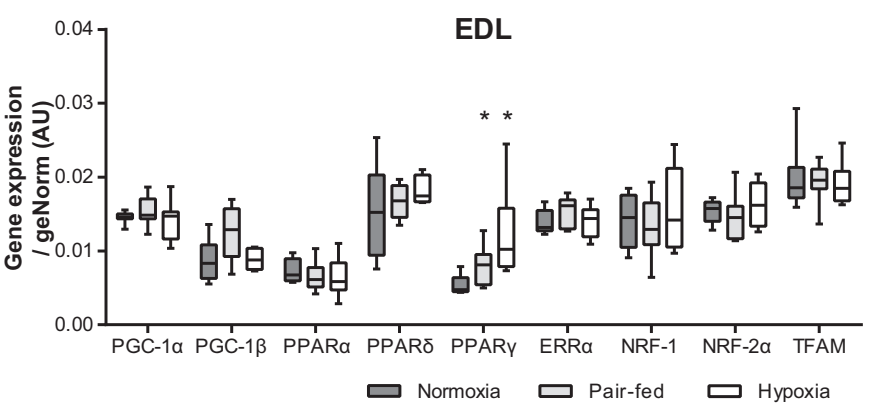

B $\frac{\pi}{x}$

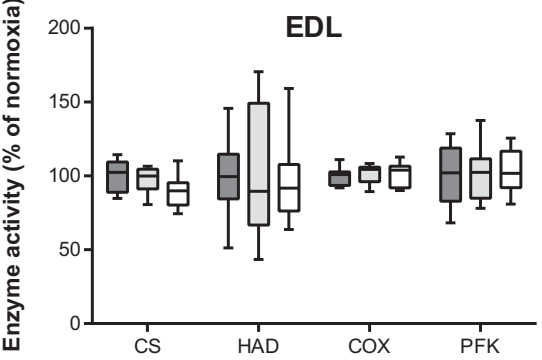

D $\underset{\&}{2} 250] \quad$ EDL
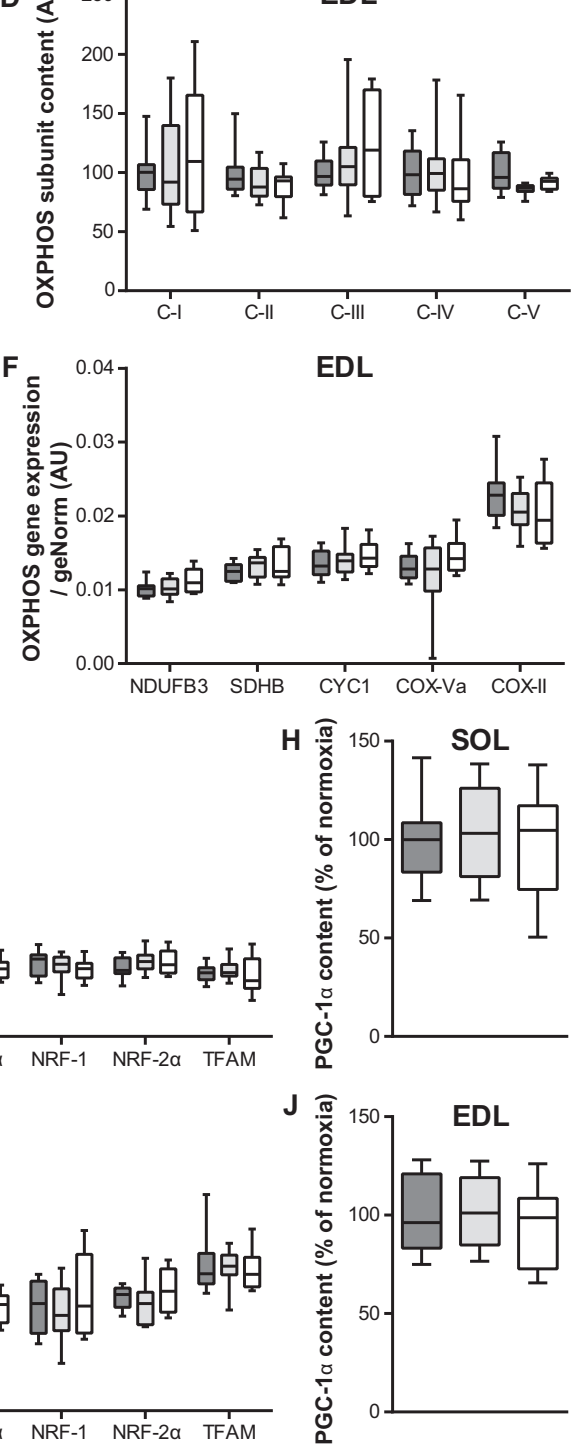

Fig. 9. In adult mice, oxidative capacity is marginally affected by hypoxia. A-B: Metabolic enzyme activity in the soleus (A) and EDL (B). C-D: Protein content of labile subunits of OXPHOS complexes in the soleus (C) and EDL (D). E-F: Gene expression of subunits of OXPHOS complexes in the soleus (E) and EDL (F). G and I: Gene expression of regulators of oxidative metabolism in the soleus (G) and EDL (I). $H$ and J: Protein content of PGC-I $\alpha$ in the soleus (H) and EDL (J). CS, citrate synthase; HAD, 3-hydroxyacyl-CoA dehydrogenase; COX, cytochrome $c$ oxidase; PFK, phosphofructokinase. NDUFB3, OXPHOS complex I; SDHB, OXPHOS complex II; CYCI, OXPHOS complex III; COX-Va, OXPHOS complex IV, nuclear encoded; COX-II, OXPHOS complex IV, mitochondrially encoded; PGC- I, PPAR gamma coactivator I; PPAR, peroxisome proliferator-activated receptor; ERR $\alpha$, estrogen-related receptor $\alpha$; NRF, nuclear respiratory factor; Tfam, mitochondrial transcription factor $A$. Number of animals per group: normoxic $n=8$, pair-fed $n=8$, hypoxic $n=8$. Box plots indicate median and interquartile range, whiskers indicate minimum and maximum. Level of significance: ${ }^{*} P<0.05$ compared to normoxic mice, \#P<0.05 compared to pair-fed mice. 


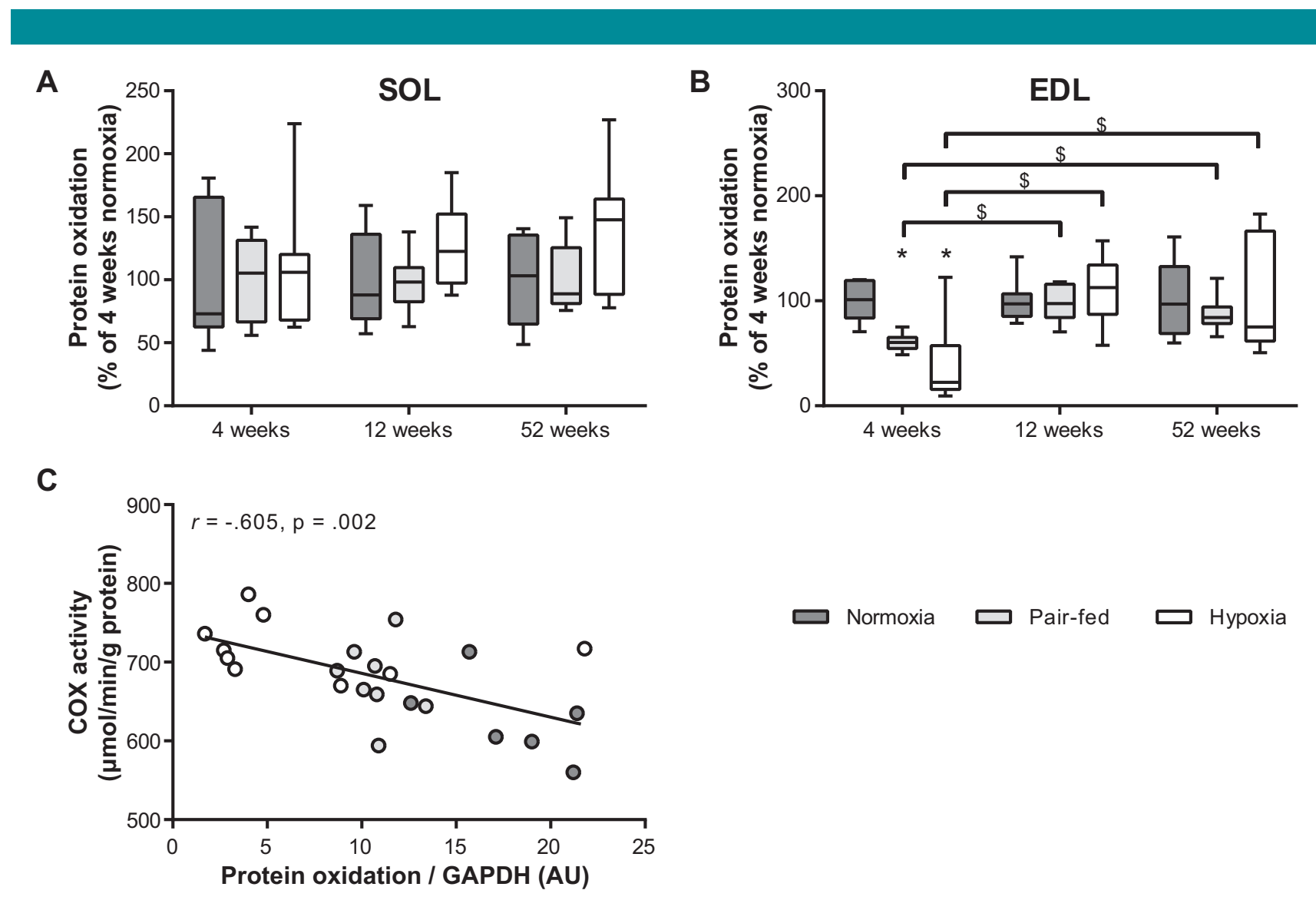

Fig. 10. Protein oxidation is only affected by hypoxia in the EDL of young mice. Protein carbonylation measured by Oxyblot in soleus (A) and EDL (B) lysates. C: Correlation of protein oxidation with cytochrome c oxidase (COX) activity in the EDL of 4-week-old mice. Number of animals per group: panel A 4 weeks normoxic $n=6$, pair-fed $n=8$, hypoxic $n=8$; 12 weeks normoxic $n=8$, pair-fed $n=7$, hypoxic $n=8$; 52 weeks normoxic $n=6$, pair-fed $n=8$, hypoxic $n=7$; panel B 4 weeks normoxic $n=6$, pair-fed $n=8$, hypoxic $n=9$; 12 weeks normoxic $n=8$, pair-fed $n=7$, hypoxic $n=8$; 52 weeks normoxic $n=5$, pair-fed $n=7$, hypoxic $n=8$; panel C 4 weeks normoxic $n=6$, pair-fed $n=8$, hypoxic $\mathbf{n}=9$. Box plots indicate median and interquartile range, whiskers indicate minimum and maximum. Level of significance: ${ }^{*} \boldsymbol{P}<0.05$ compared to normoxic mice of that particular age, $\$ P<0.05$ compared to 4-week-old mice in that particular condition.

hypoxia or less effective in compensation of hypoxia-associated stress. Moreover, it has been shown that oxidatively modified proteins are prone to degradation (Powers et al., 2007; Smuder et al., 2010), which could explain the increased fiber atrophy in hypoxic aged mice. However, we could not detect a significant difference between the levels of skeletal muscle protein carbonylation in the normoxic mice of the three age groups. Unexpectedly though, the young mice showed a decreased level of protein carbonylation in the EDL muscle with pairfeeding and hypoxia, in contrast to the adult and aged pair-fed and hypoxic mice in which protein carbonylation was unchanged. The protein carbonylation in the young mice correlated with COX activity, which was increased in the 4-week-old mice after hypoxia exposure. Fukuda et al. (2007) have reported that hypoxia stimulates the HIF-dependent replacement of COX IV isoform I (COX IV-I) with COX IV isoform 2 (COX IV-2) to optimize efficiency of respiration at lower oxygen concentrations. COX containing the COX IV-2 isoform has been shown to be more active under hypoxic conditions than COX with the COX IV-I isoform, but also to produce less $\mathrm{H}_{2} \mathrm{O}_{2}$ in hypoxia (Fukuda et al., 2007). A change in the composition of the COX protein complex could thus explain both increased COX activity and lower protein carbonylation. Future research will have to prove whether the replacement of COX IV-I with COX IV-2 occurs in mouse muscle in vivo and can account for the decrease in protein carbonylation as observed in this study. However, in mouse sternohyoid muscle (Lewis et al., 2015) and heart (Ashmore et al., 20l4), 2-3 weeks of hypoxia has previously been shown to increase protein carbonylation. It is unclear whether our results diverge from the literature due to a difference in muscle type (skeletal muscle vs. respiratory muscle and heart), as reports on protein carbonylation in skeletal muscle after chronic hypoxia are missing. Alternatively, increased hypoxiaassociated oxidative stress is resolved during the 3 weeks of exposure. Previous work from our group showed that muscle atrophy already is ongoing at 4 days into the experiment (de Theije et al., 20I5). Therefore, we are unable to disprove that a transient increase of carbonylated protein underlies muscle atrophy in our model (Lewis et al., 20I5).

The differential response of the muscle of young, adult, and aged mice to hypoxia suggests that age does matter and that the aged mouse is indeed a better model for translation of findings to elderly patients with chronic respiratory disease. In addition to the role of hypoxia in the cachectic processes of muscle and fat weight loss, we now also show that hypoxia can reduce expression of markers of mitochondrial metabolism and shift oxidative fiber types to less oxidative types. Hypoxia-associated effects on Oxphen are subtle, but compared to the clinical situation of patients with COPD, loss of Oxphen in this model occurred in a relatively short time period. 


\section{Literature Cited}

Abdelmalki A, Fimbel S, Mayet-Sornay MH, Sempore B, Favier R. 1996. Aerobic capacity and skeletal muscle properties of normoxic and hypoxic rats in response to training. Pflugers Arch 431:67I-679.

Ashmore T, Fernandez BO, Branco-Price C, West JA, Cowburn AS, Heather LC, Griffin JL, Johnson RS, Feelisch M, Murray AJ. 20I4. Dietary nitrate increases arginine availability and protects mitochondrial complex I and energetics in the hypoxic rat heart. J Physiol 592:47।5-4731.

Bastin J, Aubey F, Rotig A, Munnich A, Djouadi F. 2008. Activation of peroxisome proliferatoractivated receptor pathway stimulates the mitochondrial respiratory chain and can correct deficiencies in patients' cells lacking its components. J Clin Endocrinol Metab 93: |433-|44I

Batt J, Ahmed SS, Correa J, Bain A, Granton J. 2014. Skeletal muscle dysfunction in idiopathic pulmonary arterial hypertension. Am J Respir Cell Mol Biol 50:74-86.

Bergmeyer HU, Gawehn K, Grassl M. 1974. 3-Hydroxyacyl-CoA dehydrogenase. In:: Bergmeyer $\mathrm{HU}$, editor. Methods of enzymatic analysis. Weinheim Germany: Verlag Chemie GmbH. p 474.

Bigard AX, Sanchez H, Birot O, Serrurier B. 2000. Myosin heavy chain composition of skeletal muscles in young rats growing under hypobaric hypoxia conditions. J Appl Physiol 88:479-486.

Bloemberg D, Quadrilatero J. 2012. Rapid determination of myosin heavy chain expression in rat, mouse, and human skeletal muscle using multicolor immunofluorescence analysis. PLoS ONE 7:e35273.

Boutellier U, Howald H, di Prampero PE, Giezendanner D, Cerretelli P. 1983. Human muscle adaptations to chronic hypoxia. Prog Clin Biol Res 136:273-285.

Carlson CJ, Booth FW, Gordon SE. 1999. Skeletal muscle myostatin mRNA expression is fiber-type specific and increases during hindlimb unloading. Am J Physiol 277:R60I-R606. Crul T, Testelmans D, Spruit MA, Troosters T, Gosselink R, Geeraerts I, Decramer M, Gayan-Ramirez G. 2010. Gene expression profiling in vastus lateralis muscle during an acute exacerbation of COPD. Cell Physiol Biochem 25:49I-500.

De Palma S, Ripamonti M, Vigano A, Moriggi M, Capitanio D, Samaja M, Milano G, Cerretelli $P$, Wait R, Gelfi C. 2007. Metabolic modulation induced by chronic hypoxia in rats using a comparative proteomic analysis of skeletal muscle tissue. J Proteome Res 6:1974-1984.

de Theije C, Costes F, Langen RC, Pison C, Gosker HR. 20II. Hypoxia and muscle maintenance regulation: implications for chronic respiratory disease. Curr Opin Clin Nutr Metab Care 14:548-553.

de Theije CC, Langen RC, Lamers WH, Gosker HR, Schols AM, Kohler SE. 20I5. Differential sensitivity of oxidative and glycolytic muscles to hypoxia-induced muscle atrophy. J Appl Physiol (1985) I 18:200-211.

Decramer M, De Benedetto F, Del Ponte A, Marinari S. 2005. Systemic effects of COPD. Respir Med 99:S3-10.

Faucher M, Guillot C, Marqueste T, Kipson N, Mayet-Sornay MH, Desplanches D, Jammes Y, Badier M. 2005. Matched adaptations of electrophysiological, physiological, and histological properties of skeletal muscles in response to chronic hypoxia. Pflugers Arch 450:45-52.

Filley GF, Beckwitt HJ, Reeves JT, Mitchell RS. 1968. Chronic obstructive bronchopulmonary disease. Il. Oxygen transport in two clinical types. Am J Med 44:26-38.

Fukuda R, Zhang H, Kim JW, Shimoda L, Dang CV, Semenza GL. 2007. HIF-I regulates cytochrome oxidase subunits to optimize efficiency of respiration in hypoxic cells. Cell I29:I I I-122.

Gohil K, Edwards RHT, Jones DA. 1981. Analysis of muscle mitochondrial function with techniques applicable to needle biopsy samples. Clin Physiol I:195-207.

Gosker HR, Engelen MP, van Mameren H, van Dijk PJ, van der Vusse G], Wouters EF, Schols AM. 2002a. Muscle fiber type IIX atrophy is involved in the loss of fat-free mass in chronic obstructive pulmonary disease. Am J Clin Nutr 76:1 I3-119.

Gosker HR, van Mameren H, van Dijk PJ, Engelen MP, van der Vusse GJ, Wouters EF, Schols AM. 2002 b. Skeletal muscle fibre-type shifting and metabolic profile in patients with chronic obstructive pulmonary disease. Eur Respir J 19:617-625.

Gosker HR, Wouters EF, van der Vusse GJ, Schols AM. 2000. Skeletal muscle dysfunction in chronic obstructive pulmonary disease and chronic heart failure: Underlying mechanisms and therapy perspectives. Am J Clin Nutr 71:1033-1047.

Gouspillou G, Sgarioto N, Norris B, Barbat-Artigas S, Aubertin-Leheudre M, Morais JA, Burelle Y, Taivassalo T, Hepple RT. 2014. The relationship between muscle fiber typespecific PGC-Ialpha content and mitochondrial content varies between rodent models and humans. PLoS ONE 9:el03044.

Green HJ, Sutton JR, Cymerman A, Young PM, Houston CS. 1989. Operation Everest II: Adaptations in human skeletal muscle. J Appl Physiol 66:2454-246

Hayot M, Rodriguez J, Vernus B, Carnac G, Jean E, Allen D, Goret L, Obert P, Candau R, Bonnieu A. 20II. Myostatin up-regulation is associated with the skeletal muscle response to hypoxic stimuli. Mol Cell Endocrinol 332:38-47.

Herridge MS, Cheung AM, Tansey CM, Matte-Martyn A, Diaz-Granados N, Al-Saidi F, Cooper AB, Guest CB, Mazer CD, Mehta S, Stewart TE, Barr A, Cook D, Slutsky AS, Canadian Critical Care Trials G. 2003. One-year outcomes in survivors of the acute respiratory distress syndrome. N Engl J Med 348:683-693.

Hirofuji C, Ishihara A, Itoh K, Itoh M, Taguchi S, Takeuchi-Hayashi H. 1992. Fibre type composition of the soleus muscle in hypoxia-acclimatised rats. J Anat 181:327-333.

Hoppeler H, Desplanches D. 1992. Muscle structural modifications in hypoxia. Int J Sports Med 13:S166-S168.

HoppelerH,KleinertE,Schlegel C, ClaassenH,HowaldH,KayarSR, CerretelliP. 1990. Morphological adaptations of human skeletal muscle to chronic hypoxia. Int J Sports Med I I:S3-S9.

Howald H, Pette D, Simoneau JA, Uber A, Hoppeler H, Cerretelli P. 1990. Effect of chronic hypoxia on muscle enzyme activities. Int J Sports Med II:SIO-SI4.

Inoue T, Hashimoto M, Katakura M, Tanabe Y, Al Mamun A, Matsuzaki K, Otani H, Shido O. 2014. Effects of chronic administration of arachidonic acid on lipid profiles and morphology in the skeletal muscles of aged rats. Prostaglandins Leukot Essent Fatty Acids 91:119-127.

Ishihara A, Itho K, Itoh M, Hirofuji C, Hayashi H. 1994. Hypobaric-hypoxic exposure and histochemical responses of soleus muscle fibers in the rat. Acta Histochem 96:74-80.

Ishihara A, Itoh K, Oishi Y, Itoh M, Hirofuji C, Hayashi H. I995. Effects of hypobaric hypoxia on histochemical fibre-type composition and myosin heavy chain isoform component in the rat soleus muscle. Pflugers Arch 429:60I-606.

Itoh K, Moritani T, Ishida K, Hirofuji C, Taguchi S, Itoh M. 1990. Hypoxia-induced fibre type transformation in rat hindlimb muscles. Histochemical and electro-mechanical changes. Eur I Appl Physiol Occup Physiol 60:331-336.

Itoh M, Itoh K, Taguchi S, Hirofuji C, Takeuchi H, Ishihara A. 1992. Effect of hypobaric hypoxia on fiber type composition of the soleus muscle in the developing rat. Aviat Space Environ Med 63:583-587.

Jakobsson P, Jorfeldt L. 1995. Long-term oxygen therapy may improve skeletal muscle metabolism in advanced chronic obstructive pulmonary disease patients with chronic hypoxaemia. Respir Med 89:47I-476.
Jakobsson P, Jorfeldt L, Brundin A. 1990. Skeletal muscle metabolites and fibre types in patients with advanced chronic obstructive pulmonary disease (COPD), with and without chronic respiratory failure. Eur Respir J 3:192-196.

Jakobsson P, Jorfeldt L, Henriksson J. 1995. Metabolic enzyme activity in the quadriceps femoris muscle in patients with severe chronic obstructive pulmonary disease. Am J Respir Crit Care Med I5I:374-377.

Lainscak M, Gosker HR, Schols AM. 2013. Chronic obstructive pulmonary disease patient journey: Hospitalizations as window of opportunity for extra-pulmonary intervention. Curr Opin Clin Nutr Metab Care 16:278-283.

Lainscak M, von Haehling S, Doehner W, Sarc I, Jeric T, Ziherl K, Kosnik M, Anker SD, Suskovic S. 20I I. Body mass index and prognosis in patients hospitalized with acute exacerbation of chronic obstructive pulmonary disease. J Cachexia Sarcopenia Muscle 2:8I-86.

Lewis P, Sheehan D, Soares R, Varela Coelho A, O'Halloran KD. 2015. Chronic sustained hypoxia-induced redox remodeling causes contractile dysfunction in mouse sternohyoid muscle. Front Physiol 6:122.

Ling KH, Paetkau V, Marcus F, Lardy HA. 1966. Phosphofructokinase: I. Skeletal Muscle. Methods Enzymol: Academic Press. 425-429.

Ljubicic V, Joseph AM, Adhihetty PJ, Huang JH, Saleem A, Uguccioni G, Hood DA. 2009. Molecular basis for an attenuated mitochondrial adaptive plasticity in aged skeletal muscle. Aging (Albany NY) 1:818-830.

Lundby C, Calbet JA, Robach P. 2009. The response of human skeletal muscle tissue to hypoxia. Cell Mol Life Sci 66:3615-3623.

Lunde IG, Ekmark M, Rana ZA, Buonanno A, Gundersen K. 2007. PPARdelta expression is influenced by muscle activity and induces slow muscle properties in adult rat muscles after somatic gene transfer. J Physiol 582:1277-1287.

Marcelino MY, Fuoco NL, de Faria CA, Kozma Rde L, Marques LF, Ribeiro-Paes JT. 2014 Animal models in chronic obstructive pulmonary disease-an overview. Exp Lung Res 40:259-27I.

O'Leary MF, Vainshtein A, lqbal S, Ostojic O, Hood DA. 2013. Adaptive plasticity of autophagic proteins to denervation in aging skeletal muscle. Am J Physiol Cell Physiol 304 C422-C430.

Powers SK, Kavazis AN, McClung JM. 2007. Oxidative stress and disuse muscle atrophy. J Appl Physiol 102:2389-2397.

Radak Z, Taylor AW, Ohno H, Goto S. 200I. Adaptation to exercise-induced oxidative stress: from muscle to brain. Exerc Immunol Rev 7:90-107.

Remels AH, Gosker HR, Langen RC, Schols AM. 2013. The mechanisms of cachexia underlying muscle dysfunction in COPD. J Appl Physiol I |4:1253-1262.

Rivard A, Berthou-Soulie L, Principe N, Kearney M, Curry C, Branellec D, Semenza GL, Isner JM. 2000. Age-dependent defect in vascular endothelial growth factor expression is associated with reduced hypoxia-inducible factor I activity. J Biol Chem 275:29643-29647.

Rivard A, Fabre JE, Silver M, Chen D, Murohara T, Kearney M, Magner M, Asahara T, Isner JM. 1999. Age-dependent impairment of angiogenesis. Circulation 99:III-I20.

Sauleda J, Garcia-Palmer F, Wiesner RJ, Tarraga S, Harting I, Tomas P, Gomez C, Saus C, Palou A, Agusti AG. 1998. Cytochrome oxidase activity and mitochondrial gene expression in skeletal muscle of patients with chronic obstructive pulmonary disease. Am J Respir Crit Care Med 157:1413-1417.

Schols A, Mostert R, Soeters P, Greve LH, Wouters EF. 1989. Inventory of nutritional status in patients with COPD. Chest 96:247-249.

Schreiber SN, Emter R, Hock MB, Knutti D, Cardenas J, Podvinec M, Oakeley EJ, Kralli A 2004. The estrogen-related receptor alpha (ERRalpha) functions in PPARgamma coactivator I alpha (PGC-I alpha)-induced mitochondrial biogenesis. Proc Natl Acad Sci USA 101:6472-6477.

Shepherd D, Garland PB. 1969. Citrate synthase from rat liver. Methods Enzymol: Academic Press. P II-16.

Sillau AH, Banchero N. 1977. Effects of hypoxia on capillary density and fiber composition in rat skeletal muscle. Pflugers Arch 370:227-232.

Slot IG, Schols AM, Vosse BA, Kelders MC, Gosker HR. 2014. Hypoxia differentially regulates muscle oxidative fiber type and metabolism in a HIF-Ialpha-dependent manner. Cell Signal 26:1837-1845.

Smuder AJ, Kavazis AN, Hudson MB, Nelson WB, Powers SK. 2010. Oxidation enhances myofibrillar protein degradation via calpain and caspase-3. Free Radic Biol Med 49:1 I $52-1160$. Takahashi H, Asano K, Nakayama H. 1996. Effect of endurance training under hypoxic condition on oxidative enzyme activity in rat skeletal muscle. Appl Human Sci I5: I I I-I I 4.

Takahashi H, Kikuchi K, Nakayama H. 1992. Effect of chronic hypoxia on skeletal muscle fiber type in adult male rats. Ann Physiol Anthropol II:625-630.

Takahashi H, Kikuchi K, Nakayama H. 1993. Effect of chronic hypoxia on oxidative enzyme activity in rat skeletal muscle. Ann Physiol Anthropol 12:363-369.

Turan N, Kalko S, Stincone A, Clarke K, Sabah A, Howlett K, Curnow SJ, Rodriguez DA Cascante M, O'Neill L, Egginton S, Roca J, Falciani F. 20II. A systems biology approach identifies molecular networks defining skeletal muscle abnormalities in chronic obstructive pulmonary disease. PLoS Comput Biol 7:e1002129.

van den Borst B, Schols AM, de Theije C, Boots AW, Kohler SE, Goossens GH, Gosker HR. 2013a. Characterization of the inflammatory and metabolic profile of adipose tissue in a mouse model of chronic hypoxia. J Appl Physiol II4:1619-1628.

van den Borst B, Slot IG, Hellwig VA, Vosse BA, Kelders MC, Barreiro E, Schols AM, Gosker HR. 20I3b. Loss of quadriceps muscle oxidative phenotype and decreased endurance in patients with mild-to-moderate COPD. J Appl Physiol I 14:1319-1328.

Vandesompele J, De Preter K, Pattyn F, Poppe B, Van Roy N, De Paepe A, Speleman F. 2002 Accurate normalization of real-time quantitative RT-PCR data by geometric averaging of multiple internal control genes. Genome Biol 3:RESEARCH0034.

Verdijk LB, Koopman R, Schaart G, Meijer K, Savelberg HH, van Loon LJ. 2007. Satellite cell content is specifically reduced in type II skeletal muscle fibers in the elderly. Am J Physiol Endocrinol Metab 292:EI5I-EI57.

Wigston DJ, English AW. 1992. Fiber-type proportions in mammalian soleus muscle during postnatal development. J Neurobiol 23:6I-70.

Wu Z, Puigserver P, Andersson U, Zhang C, Adelmant G, Mootha V, Troy A, Cinti S, Lowell B, Scarpulla RC, Spiegelman BM. 1999. Mechanisms controlling mitochondrial biogenesis and respiration through the thermogenic coactivator PGC-I. Cell 98:II5-124.

Wuyam B, Payen JF, Levy P, Bensaidane H, Reutenauer H, Le Bas JF, Benabid AL. 1992. Metabolism and aerobic capacity of skeletal muscle in chronic respiratory failure related to chronic obstructive pulmonary disease. Eur Respir J 5:157-162.

\section{Supporting Information}

Additional supporting information may be found in the online version of this article at the publisher's web-site. 